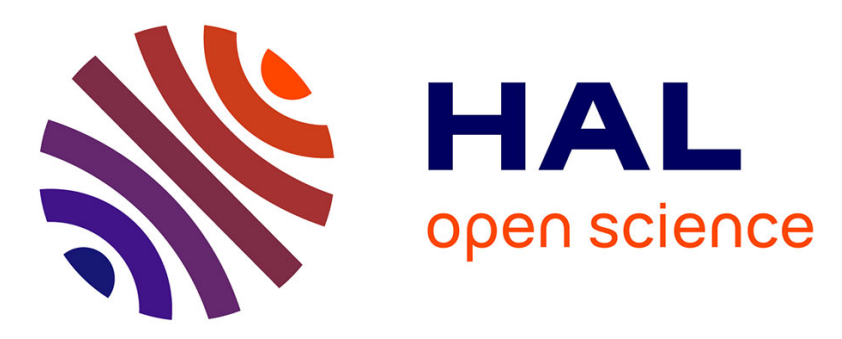

\title{
Rip It off: Nitro to Nitroso Reduction by Iron Half-Sandwich Complexes
}

\author{
Marcus Korb, Seyed Mohammad Bagher Hosseini Ghazvini, Stephen A \\ Moggach, Jean-François Meunier, Azzedine Bousseksou, Paul Low
}

\section{- To cite this version:}

Marcus Korb, Seyed Mohammad Bagher Hosseini Ghazvini, Stephen A Moggach, Jean-François Meunier, Azzedine Bousseksou, et al.. Rip It off: Nitro to Nitroso Reduction by Iron Half-Sandwich Complexes. Inorganic Chemistry, 2021, 60 (7), pp.4986-4995. 10.1021/acs.inorgchem.1c00042 . hal03225433

\section{HAL Id: hal-03225433 \\ https://hal.science/hal-03225433}

Submitted on 12 May 2021

HAL is a multi-disciplinary open access archive for the deposit and dissemination of scientific research documents, whether they are published or not. The documents may come from teaching and research institutions in France or abroad, or from public or private research centers.
L'archive ouverte pluridisciplinaire HAL, est destinée au dépôt et à la diffusion de documents scientifiques de niveau recherche, publiés ou non, émanant des établissements d'enseignement et de recherche français ou étrangers, des laboratoires publics ou privés. 


\title{
Rip it off: Nitro to Nitroso Reduction by Iron Half-sandwich Com- plexes
}

\author{
Marcus Korb*, ${ }^{[a]}$ S. Mohammad B. Hosseini-Ghazvini, ${ }^{[a]}$ Stephen A. Moggach, ${ }^{\text {[a] }}$ Jean-François \\ Meunier, ${ }^{[\mathrm{b}]}$ Azzedine Bousseksou, ${ }^{[\mathrm{b}]}$ Paul J. Low ${ }^{[\mathrm{a}]}$
}

[a] Dr. M. Korb, Mr S. M. B. Hosseini-Ghazvini, Prof. P. J. Low; The University of Western Australia, School of Molecular Sciences, 35 Stirling Highway, Crawley, Perth, Western Australia 6009, Australia

E-mail: marcus.korb@uwa.edu.au; paul.low@uwa.edu.au

[b] J.-F. Meunier, Prof. A. Bousseksou; CNRS, Université de Toulouse, Laboratoire de Chimie de Coordination, 205 route de Narbonne, 31077 Toulouse, France

Deoxygenation, Iron, Half-Sandwich, Nitro, Nitroso, Moessbauer

\begin{abstract}
Activation of $[\mathrm{FeCl}(\mathrm{dppe}) \mathrm{Cp}](\mathbf{1})$ by chloride abstraction with $\mathrm{Na}\left[\mathrm{BAr}^{\mathrm{X}}{ }_{4}\right]\left(\mathrm{X}=\mathrm{F}\right.$ : $\left[\mathrm{B}\left(3,5-\left(\mathrm{CF}_{3}\right)_{2}-\mathrm{C}_{6} \mathrm{H}_{3}\right)_{4}\right] ; \mathrm{X}=\mathrm{Cl}$ : $\left.\left[\mathrm{B}\left(3,5-\mathrm{Cl}_{2}-\mathrm{C}_{6} \mathrm{H}_{3}\right)_{4}\right]\right)$ permits reaction with a range of nitro aromatics, $\mathrm{RC}_{6} \mathrm{H}_{4} \mathrm{NO}_{2}\left(\mathrm{R}=\right.$ halogen, $\mathrm{Me}, \mathrm{OMe}, \mathrm{NO}_{2}$ or $\left.\mathrm{NMe}_{2}\right)$ to give cationic iron nitroso complexes $\left[\mathrm{Fe}\left\{\mathrm{N}(\mathrm{O})-\mathrm{C}_{6} \mathrm{H}_{4} \mathrm{R}\right\}(\mathrm{dppe}) \mathrm{Cp}\right]^{+}\left([\mathbf{3}]^{+}\right)$. Similar reactions of $\mathbf{1}$ and $\mathrm{Na}\left[\mathrm{BAr}{ }_{4}\right] \quad$ with $\left[\mathrm{Fe}\left(\mathrm{NCC}_{6} \mathrm{H}_{4} \mathrm{NO}_{2}\right)(\right.$ dppe $\left.) \mathrm{Cp}\right]\left[\mathrm{BAr}_{4}{ }_{4}\right]$ gave bimetallic $\left[\{\mathrm{Fe}(\mathrm{dppe}) \mathrm{Cp}\}_{2}\left\{\mu-\mathrm{N} \equiv \mathrm{CC}_{6} \mathrm{H}_{4} \mathrm{~N}(\mathrm{O})\right\}\right]\left[\mathrm{BAr}_{4}^{\mathrm{F}}\right]_{2}$. However, reactions of 1 and $\mathrm{Na}\left[\mathrm{BAr}_{4}{ }_{4}\right]$ with 4-nitrophenol gave the first example of a bench-stable iron half-sandwich phenolate complex $\left[\mathrm{Fe}\left(\mathrm{OC}_{6} \mathrm{H}_{4} \mathrm{NO}_{2}\right)(\mathrm{dppe}) \mathrm{Cp}\right]^{+}$rather than $\mathrm{NO}_{2}$ activation. The formation of complexes [3] ${ }^{+}$likely proceeds via the unusual, bluecoloured bimetallic species $\left[\{\mathrm{Fe}(\mathrm{dppe}) \mathrm{Cp}\}_{2}\left\{\mu, \kappa^{2} O, O^{\prime}-\mathrm{O}_{2} \mathrm{NAr}\right\}\right]^{2+}$. This compound undergoes $\mathrm{N}-\mathrm{O}$ bond cleavage resulting in $[3]^{+}$ and a $\mathrm{Fe}^{\mathrm{IV}}=\mathrm{O}$ species, which reacts via an internal $\mathrm{C}-\mathrm{H}$ activation of the dppe ligand to give $\left[\mathrm{Fe}^{\mathrm{III}}\left(\kappa^{3} O, P, P^{\prime}-\mathrm{P}\left(2-\mathrm{O}-\mathrm{C}_{6} \mathrm{H}_{4}\right)(\mathrm{Ph})-\mathrm{C}_{2} \mathrm{H}_{4-}\right.\right.$ $\left.\left.\mathrm{PPh}_{2}\right) \mathrm{Cp}\right]^{+}$. Complexes $[3]^{+}$are stable under ambient conditions, readily purified by column chromatography and isolated in up to $50 \%$ yield, considering 0.5 equiv of $\mathbf{1}$ to be required as the oxygen acceptor.
\end{abstract}

\section{INTRODUCTION}

The activation of small molecules through controlled modification of common functional groups is a key aspect of modern chemical synthetic strategies by providing access to unusual or unstable moieties. With a view to increasing the sustainability of chemical processes, a fast growing area of research seeks to undertake these activation steps with earth abundant elements of low inherent toxicity. ${ }^{1}$ For example, whilst nitroso compounds (RNO) are known as versatile synthetic reagents, ${ }^{2}$ and as non-innocent, redox-active ligands ${ }^{3,4}$ in various transition metal complexes, ${ }^{5}$ studies of nitroso compounds are complicated by the inconvenient methods known for their synthesis ${ }^{6}$ and the limited range of commercially available examples. Nevertheless, the coordination chemistry of nitroso compounds is of special interest and can be used to mimic molecular oxygen in e.g. $\mathrm{Cu}^{7}$ and $\mathrm{Fe}^{8}$ complexes. However, the remarkable stability of nitroso ligands also causes deactivation of iron-based enzymes, including haemoglobin, for which they are considered as end products of nitroarene poisoning in the human body. ${ }^{9,11}$

Although, nitroso ligands in iron porphyrin-based compounds and iron complexes of other macrocyclic ligand systems have been intensely studied in this context, ${ }^{3,10}$ the range of com- plexes featuring nitroso ligands remains limited, due to the inconvenient methods for the synthesis of nitroso compounds and limited range of commercially available examples. For transition metals other than iron, such as $\mathrm{Co}^{11}{ }^{11} \mathrm{Ni}^{12}$ and $\mathrm{Ru}^{13,14}$, reduction of nitro- to nitrosoarenes is known for a broader range of complex types, whereby phosphines or carbonyl ligands commonly act as reducing agents and oxygen acceptors, forming $\mathrm{O}=\mathrm{PPh}_{3}$ and $\mathrm{CO}_{2}$, respectively. In some Ru-based examples, the complex itself was also able to act as the oxygen acceptor, with the extruded oxygen atom incorporated within the ancillary ligand scaffold as new $o$-formy ${ }^{14}$ and hydroxy $1^{13}$ functional groups. The most important features and developments of the chemistry of Ru nitroso complexes have recently been reviewed, highlighting the importance of this ligand entity. ${ }^{15}$

Despite the prevalence of nitro-substituted aryl halides as coupling partners in late metal catalysed cross-coupling reactions, examples of such substrates with iron and other first-row metal catalysts are conspicuously absent. This hints at difficulties in achieving transformations of these nitro-substituted substrates and merits further investigation of the interactions of nitro arenes with iron complexes. ${ }^{16}$

The iron half-sandwich fragment is known for its stability and strong metal-to-ligand backbonding properties, ${ }^{17}$ making it an 
ideal platform upon which to further explore nitroso ligand chemistry. However few nitroso complexes of the FeCp moiety are known and generalised synthetic procedures have proven elusive. The first such complexes were prepared from the reaction of $\left[\mathrm{FeI}(\mathrm{CO})_{2} \mathrm{Cp}\right]$ with $\mathrm{AgPF}_{6}$ and $\mathrm{PhNO}^{18}$ The second example known to date has been identified from the $\left[\mathrm{Fe}(\mathrm{NCMe})\left\{\mathrm{PPh}_{2}\left(2-\mathrm{S}_{-} \mathrm{C}_{6} \mathrm{H}_{4}\right)\right\} \mathrm{Cp}^{*}\right]$ precursor, which upon dissociation of the labile NCMe ligand, can reversibly bind nitrosoarenes formed in situ by reduction from their parent nitroarenes with (EtO) $)_{3} \mathrm{SiH}$ as a part of an iron-based catalytic cycle (Scheme 1). ${ }^{19}$ In absence of the reducing agent the iron complex directly reduced the nitro precursor, with the extruded oxygen atom being captured by the phosphine ligand. However, a convenient and general method for the preparation of iron half-sandwich nitroso complexes is still pending.

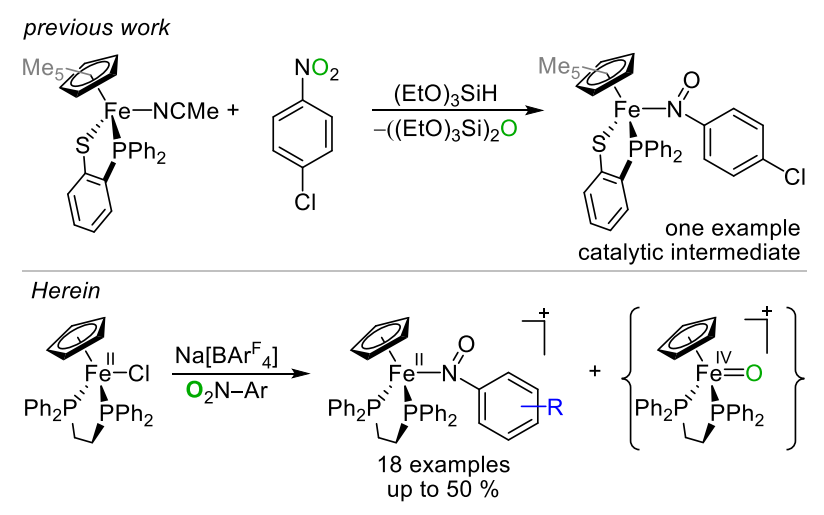

Scheme 1. Coordination of a nitrosoarene prepared from in situ reduction of a nitroarene substrate (top) ${ }^{19}$ and the deoxygenation of nitroarenes leading to the synthesis of iron nitroso complexes described in the present work.

Here we present a straight-forward approach to the preparation of nitroso compounds by the deoxygenation of common nitroarenes within the coordination sphere of the simple halfsandwich complex $[\mathrm{Fe}(\mathrm{dppe}) \mathrm{Cp}]\left[\mathrm{BAr}_{4}{ }_{4}\right](\mathrm{X}=\mathrm{F}$ : $[\mathrm{B}(3,5-$ $\left.\left.\left(\mathrm{CF}_{3}\right)_{2}-\mathrm{C}_{6} \mathrm{H}_{3}\right)_{4}\right] ; \mathrm{X}=\mathrm{Cl}$ : $\left.\left[\mathrm{B}\left(3,5-\mathrm{Cl}_{2}-\mathrm{C}_{6} \mathrm{H}_{3}\right)_{4}\right]\right)$ via a bimetallic intermediate. Whilst one metal fragment captures the nitroso moiety to give stable nitroso complexes, the other acts as the oxygen acceptor.

\section{RESULTS AND DISCUSSION}

The nitroso compounds $[\mathbf{3 a}-\mathbf{v}]^{+}$were obtained from reaction of $[\mathrm{FeCl}(\mathrm{dppe}) \mathrm{Cp}](\mathbf{1})^{20}$ with an excess of any one of the various nitroarenes 2 and the sodium salts of the weakly coordinating borate anions $\left[\mathrm{BAr}_{4}\right]^{-}\left(=\left[\mathrm{B}\left(3,5-\left(\mathrm{CF}_{3}\right)_{2}-\mathrm{C}_{6} \mathrm{H}_{3}\right)_{4}\right]^{-}\right)$and $\left[\mathrm{BAr}_{4}\right]^{-}\left(=\left[\mathrm{B}\left(3,5-\mathrm{Cl}_{2}-\mathrm{C}_{6} \mathrm{H}_{3}\right)_{4}\right]^{-}\right)$in toluene $\left(18 \mathrm{~h}, 70^{\circ} \mathrm{C}\right)$ (Scheme 2).

The $\mathrm{Na}\left[\mathrm{BAr}^{\mathrm{X}}{ }_{4}\right]$ salts likely help drive the reaction through the precipitation of $\mathrm{NaCl},{ }^{21}$ whilst the weakly coordinating borate anions impart solubility of the iron complex salts in toluene, making the coordinatively unsaturated Fe moiety available for the reaction with the substrates. The crude reaction mixtures can be purified by column chromatography, allowing the excess of the nitroarene to be recovered and isolation of the nitroso complexes $[\mathbf{3 a}-\mathbf{v}]\left[\mathrm{BAr}_{4}{ }_{4}\right]$ together with the $\mathrm{Fe}^{\mathrm{III}}$ byproduct [4][BAr ${ }_{4}$ ] (Scheme 2). In some cases the similar polarities of the salts of $[3]^{+}$and $[4]^{+}$made separation by column chromatography difficult, accounting for the variable isolated yield of the by-product. The reaction tolerates a wide variety of substituted nitroarenes. However, reactions with nitroarenes bearing $\pi$-electron-donating groups such as $p$-F (2b), $p$-OMe (2h) and $\mathrm{NR}_{2}(\mathbf{2 o}, \mathbf{p})$ resulted in lower yields, independent of the borate counter ion. This may be due to one or more factors including the stronger $\mathrm{N}$... O bonds in the electron-rich nitro compounds 2 or weaker $\mathrm{Fe}-\mathrm{N}(\mathrm{O})$ bonds in the respective nitroso products (see below). Aliphatic substrates are less well behaved under these reaction conditions, with reaction of $\mathbf{1}$ with 2-nitropropane giving several unidentified by-products in addition to low yields of $[\mathbf{3 f}]^{+}$. The presence of acidic $\mathrm{OH}$ groups as in 4-nitrophenol $(\mathbf{2 g})$ or 4-nitrobenzoic acid $(\mathbf{2 q})$ resulted in the formation of oxidized $\mathrm{Fe}^{\mathrm{III}}$ phenolate $[6]\left[\mathrm{BAr}{ }_{4}^{\mathrm{Cl} / \mathrm{F}}\right]$ or chloride [4][BAr ${ }_{4}^{\mathrm{Cl} / \mathrm{F}}$ ] complexes, respectively, rather than the nitroso compounds $[\mathbf{3 g}]^{+}$or $[\mathbf{3 q}]^{+}$. In passing we note that $[6]^{+}$appears to the first bench-stable example of an iron half-sandwich phenolate complex to have been isolated, previous investigations were limited to reactive low-valent 14 and $16 \mathrm{VE}$ complexes $^{22}$ and computational studies. ${ }^{23,24,37}$ Reactions of 1 with $\mathrm{Na}\left[\mathrm{BAr}_{4}{ }_{4}\right]$ and inorganic nitro compounds, such as sodium nitrate and nitrite failed to give nitroso complexes but rather gave [4][BArCl$\left.{ }_{4}\right]$, in $11 \%$ and $29 \%$ yield, respectively. The coordinatively unsaturated species $[\mathrm{Fe}(\mathrm{dppe}) \mathrm{Cp}]\left[\mathrm{BAr}_{4}{ }_{4}\right]$ has been shown to promote internal alkyne-vinylidene rearrangements under conditions similar to those employed here. ${ }^{21}$ A competition experiment in which $[\mathrm{FeCl}(\mathrm{dppe}) \mathrm{Cp}]$ was reacted with 4 equiv of both $\mathrm{PhC} \equiv \mathrm{CPh}$ and $2 \mathbf{e}$ (used for a better distinction from resonances from other aromatic entities) in presence of $\mathrm{Na}\left[\mathrm{BAr}_{4}{ }_{4}\right]$ gave the nitroso complex $[\mathbf{3 e}]^{+}$exclusively. In the case of reactions of [FeCl(dppe)Cp], $\mathrm{Na}\left[\mathrm{BAr}_{4}{ }_{4}\right]$ and either of the internal alkynes $\mathbf{2 s}, \mathbf{2 u}$, the nitroso complexes $[3 \mathbf{s}, \mathbf{u}]\left[\mathrm{BAr}^{\mathrm{F}}{ }_{4}\right]$ were obtained in $44 \%$ and $29 \%$ yield, respectively, together with $[4]\left[\mathrm{BAr}^{\mathrm{F}}\right]_{4}$ in low yield (Scheme 2). It can therefore be concluded that the nitro-nitroso reduction is favoured compared to the internal alkyne-vinylidene rearrangement under these conditions. However, in contrast to 4-nitrophenol $(\mathbf{2 g})$, reaction with the hydroxyl functionality in alkynol $\mathbf{2} \mathbf{u}$ was not observed, most probably due to the steric demand of the $\mathrm{C}\left(\mathrm{CH}_{3}\right)_{2} \mathrm{OH}$ fragment, and $[3 \mathbf{u}]\left[\mathrm{BAr}^{\mathrm{F}}{ }_{4}\right]$ was isolated in $29 \%$ yield. Reactions with the analogous $\mathrm{CH}_{2} \mathrm{OH}$ derivative $\mathbf{2 t}$, where the hydroxyl functionality is more accessible, only $[4]^{+}$and ortho- $\mathrm{CH}$ activated $[5]^{+}$(Figure 2; vide infra) were isolated as the $\left[\mathrm{BAr}_{4}\right]^{-}$ salts. The ether $\mathbf{2 v}$ gave only trace amounts of products derived from an alkyne-vinylidene rearrangement together with $[3 \mathbf{v}]^{+}$in low yield. 


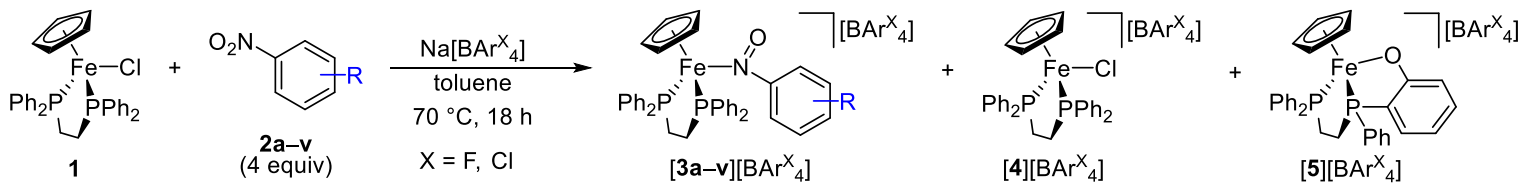

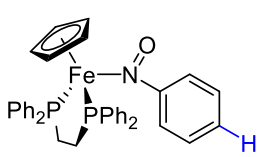

[3a][BArF ${ }_{4}$ ], $43 \%$ a)

[3a] $\left[\mathrm{BAr}_{4}{ }_{4}\right.$ ], $24 \%{ }^{\mathrm{a}, \mathrm{b}}$ )

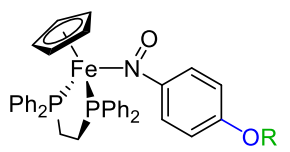

[3g] $\left.\left[\mathrm{BAr}_{4}^{\mathrm{F} / \mathrm{Cl}}\right](\mathrm{R}=\mathrm{H}), \quad 0 \% \mathrm{e}\right)$ [3h] $\left[\mathrm{BAr}_{4}\right]\left(\mathrm{R}=\mathrm{CH}_{3}\right), \quad 19 \%$ a,b) [3h] $\left.\mathrm{BAr}_{4}{ }_{4}\right]\left(\mathrm{R}=\mathrm{CH}_{3}\right), 19 \%{ }^{\mathrm{a}, \mathrm{b})}$

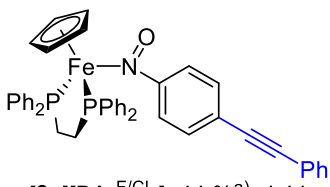

[3s] $\left.\mathrm{BAr}^{\mathrm{F} / \mathrm{Cl}}{ }_{4}\right], 44 \%$ a) yield

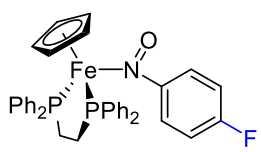

[3b][BAr ${ }_{4}$ ], $20 \%$ a) [3b] $\left[\mathrm{BAr}_{4}^{\mathrm{Cl}}\right], \quad 9 \%$ a)

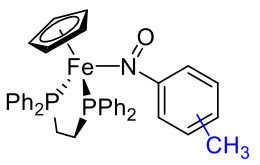

[3i] $\left.\left[\mathrm{BAr}_{4}\right](0-), \quad 0 \% \mathrm{~h}\right)$ $[3 \mathrm{j}]\left[\mathrm{BAr}_{4}\right](m-), 43 \%{ }^{\mathrm{a})}$ [3k][BAr $\left.{ }_{4}\right]$ ] $(p-), 35 \%$ a)

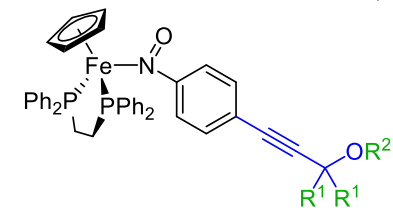

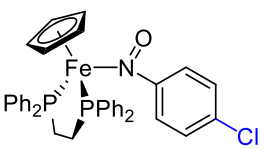

[3c][BArF${ }_{4}$ ], $41 \%$ a) [3c] $\left[\mathrm{BAr}_{4}{ }_{4}\right], 42 \%$ a)

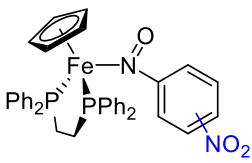

[3I][BArF $\left.{ }_{4}\right] \quad(m-), 3 \%{ }^{a)}$ $[3 \mathrm{~m}]\left[\mathrm{BAr}_{4}\right](p-), 37 \%$ $\left.[3 \mathrm{~m}]\left[\mathrm{BAr}_{4}\right](p-), 36 \%{ }^{\mathrm{f}}\right)$ $\left.[3 \mathrm{~m}]\left[\mathrm{BAr}^{\mathrm{Cl}}{ }_{4}\right](p-), 0 \% \mathrm{~h}\right)$

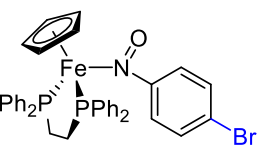

[3d] $\left[\mathrm{BAr}_{4}{ }_{4}\right], 45 \%$ a) [3d] [BArCl ${ }_{4}$ ], $47 \%$ a,b,c) $18 \%^{a, d)}$

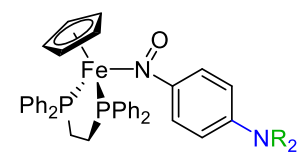

$[3 n]\left[B A r_{4}\right](R=H), \quad 0 \%{ }^{h)}$ $[30]\left[\mathrm{BAr}_{4}\right]\left(\mathrm{R}=\mathrm{CH}_{3}\right), 3 \%$ $89 \% \mathrm{~g})$

$[3 p]\left[B^{2} F_{4}\right](R=P h), \quad 9 \%$

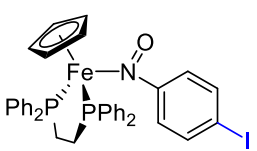

[3e][BAr $\left.{ }_{4}\right], 41 \%$ a) $[3 e]\left[\mathrm{BAr}_{4}{ }_{4}\right], 34 \% \mathrm{a}$ )

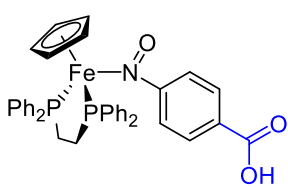

$[3 q]\left[B r_{4}{ }_{4}\right], 0 \%$ h)

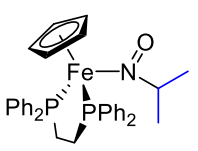

[3f] $\left.\mathrm{BAr}_{4} \mathrm{~F}_{4}\right]$, $<3 \% a, b)$

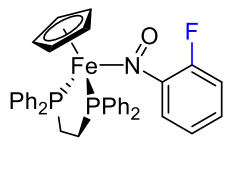

$[3 r]\left[\mathrm{BAr}_{4}\right], 50 \%$ a)

Scheme 2. Synthesis and substrate scope of Fe nitroso complexes [3a-v] $\left.\mathrm{BAr}_{4}{ }_{4}\right]$ from $[\mathrm{FeCl}(\mathrm{dppe}) \mathrm{Cp}](\mathbf{1})$ and the respective nitroarenes 2a-v. Counter ions: $\left[\mathrm{BAr}{ }_{4}\right]^{-}=\left[\mathrm{B}\left(3,5-\left(\mathrm{CF}_{3}\right)_{2}-\mathrm{C}_{6} \mathrm{H}_{3}\right)_{4}\right]^{-} ;\left[\mathrm{BAr}{ }_{4}^{\mathrm{Cl}}\right]^{-}=\left[\mathrm{B}\left(3,5-\mathrm{Cl}_{2}-\mathrm{C}_{6} \mathrm{H}_{3}\right)_{4}\right]^{-}$; note: 0.5 equiv of $\mathbf{1}$ act as the oxygen acceptor (Scheme 3), wherefore yields higher than $50 \%$ cannot be obtained; a) If the Fe ${ }^{\mathrm{III}}$ species $[4]^{+}$is present, NMR corrected yields are given; b) $\mathrm{PhC} \equiv \mathrm{CPh}$ (1 equiv) was added during synthesis, c) 8 equiv of the nitroarene were used; d) 1 (2 equiv), $\mathrm{Na}\left[\mathrm{BAr}_{4}^{\mathrm{Cl}}\right.$ ] (2 equiv) and $\mathbf{2}$ (1 equiv) were used, yield based on $\mathbf{2}$; e) compound [6] ${ }^{+}$was formed instead; $\mathrm{f}$ ) a $\left.\mathbf{1}: \mathrm{Na}^{\mathrm{B} A \mathrm{~B}^{\mathrm{F}}}{ }_{4}\right]$ : 2 ratio of $5: 5: 1$ was used, yield based on 2; g) $N, N$-dimethyl-4-nitrosoaniline instead of $N, N$-dimethyl-4-nitroaniline was reacted; h) compound $[4]\left[\mathrm{BAr}_{4}^{\mathrm{F}}\right]$ was formed instead.

In contrast to the reactions of $[\mathrm{Fe}(\mathrm{dppe}) \mathrm{Cp}]^{+}$with internal alkynes, the presence of a terminal alkyne $(\mathbf{2 w})$ or coordinating nitrile (2x) functional group prevented the formation of the nitroso complexes $[\mathbf{3 w}, \mathbf{x}]^{+}$and instead gave the acetylide complex [7a] (after deprotonation of the intermediate vinylidene) and the simple nitrile complex $[7 \mathbf{b}]^{+}$in over $50 \%$ yield, respectively (Scheme 3).

The latter compounds are identical with those products obtained by established procedures (ESI) and were identified by e.g. NMR spectroscopy and single crystal X-ray diffraction (Figures S25, S26). With the terminal alkyne and nitrile functional groups in $[\mathbf{7 a}]$ and $[\mathbf{7 b}]^{+}$effectively masked by coordination to the iron centre, these complexes were subsequently reacted with an excess of $\mathbf{1}$ and $\mathrm{Na}\left[\mathrm{BAr}^{\mathrm{F}}{ }_{4}\right]$, resulting in bimetallic $[\mathbf{8 a}]^{+}$and $[\mathbf{8 b}]^{2+}$ which were isolated in low yield after purification of the reaction mixture by column chromatography. The bimetallic complexes decompose by dissociation of the nitrile coordinated metal fragment of $[\mathbf{8 b}]\left[\mathrm{BAr}_{4}\right]_{2}$ giving $[3 \mathbf{x}]\left[\mathrm{BAr}_{4}{ }_{4}\right]$ (Scheme 3, Figure S19), or by re-protonation of $[\mathbf{8 a}]\left[\mathrm{BAr}_{4}{ }_{4}\right]$ to give of [7a]. Although attempts to similarly activate the remaining nitro functionality in $[\mathbf{3 m}]^{+}$to produce bimetallic $[3 \mathbf{y y}]^{2+}$ failed, the latter could instead be obtained by reaction of 1,4-dinitrobenzene ( $\mathbf{2 m})$ with a 5-fold excess of $\mathbf{1} / \mathrm{Na}\left[\mathrm{BAr}_{4}{ }_{4}\right]$ (Scheme 3), also in low overall isolated yield.
The nitroso cations $[3]^{+}$are characterised by $\tilde{\mathrm{v}}(\mathrm{NO})$ bands at $\sim 1290$ and $1283 \mathrm{~cm}^{-1} 25$ and by a ${ }^{31} \mathrm{P}\left\{{ }^{1} \mathrm{H}\right\}$ NMR resonance at $97-104 \mathrm{ppm}$, the precise chemical shift being in good correlation with the electron density of the nitroso-substituent (Figure S17). Electron donating groups, such as $p-\mathrm{OCH}_{3}\left([\mathbf{3 h}]^{+}\right.$; $103.2 \mathrm{ppm})$ and $p-\mathrm{NMe}_{2}\left([\mathbf{3 o}]^{+}, 103.8 \mathrm{ppm}\right)$ cause a slight lowfield shift, whereas the resonance in the $p$ - $\mathrm{NO}_{2}$-derivative $[3 \mathrm{~m}]^{+}$is shifted to higher-field and found at $101.3 \mathrm{ppm}$ (Table S4). The bimetallic compounds $[\mathbf{8 a} / \mathbf{b}]^{+/ 2+}$ exhibit two singlets in the ${ }^{31} \mathrm{P}\left\{{ }^{1} \mathrm{H}\right\} \mathrm{NMR}$ at 92.1, 102.2 and 97.0, $100.8 \mathrm{ppm}$, respectively. The symmetric bimetallic complex $[3 \mathbf{3 y}]^{2+}$ revealed a low-field shift in the ${ }^{31} \mathrm{P}\left\{{ }^{1} \mathrm{H}\right\}$ NMR (103.4 ppm) compared to monometallic $[\mathbf{3 m}]^{+}(101.3 \mathrm{ppm})$.

Correlation of the ${ }^{31} \mathrm{P}\left\{{ }^{1} \mathrm{H}\right\}$ NMR resonances with Hammett parameters ${ }^{26}$ of the substituents attached in meta $\left(\sigma_{m}\right)$ and para $\left(\sigma_{p}\right)$ position of the nitrosoarene ligand, results in a linear fit (Figure S17; $\mathrm{R}^{2}=0.9214$ ) and allowed for determination of parameters as yet unreported for the substituents in $[\mathbf{3 u}]^{+}\left(\sigma_{p}=\right.$ $0.20),[\mathbf{3 v}]^{+}\left(\sigma_{p}=0.22\right),[\mathbf{3 y}]^{2+}\left(\sigma_{p}=-0.55\right),[\mathbf{8 a}]^{+}\left(\sigma_{p}=0.28\right)$ and $[\mathbf{8 b}]^{2+}\left(\sigma_{p}=1.23\right)$. The ${ }^{13} \mathrm{C}\left\{{ }^{1} \mathrm{H}\right\}$ shift of the $\mathrm{Cp}$ moiety also proved sensitive to the electronic nature of the nitroso ligand substituent (Figure S16). An examination of the ${ }^{13} \mathrm{C}\left\{{ }^{1} \mathrm{H}\right\}$ NMR data reveals that the chemical shift of the $\mathrm{Cp}$ ligand is affected by the push-pull character between electron-donating $\left(\mathrm{NMe}_{2}\right.$, 
$\left.\mathrm{NPh}_{2}\right)$ and the withdrawing nitroso substituent $\left(\sigma_{\mathrm{p}}=0.91\right)$. Thus, the $\mathrm{R}^{2}$ value of the fitting is enhanced from 0.8006 to 0.9495 , if the push-pull-corrected ${\sigma_{\mathrm{p}}}^{+}$parameters are considered. To the best of our knowledge ${\sigma_{\mathrm{p}}}^{+}$is not yet available for the $\mathrm{NPh}_{2}$ group $\left([\mathbf{3 p}]^{+}\right)$and was calculated as ${\sigma_{\mathrm{p}}}^{+}=-0.89$ (Table S4, Figure S16). The push-pull effect causes a bathochromic shift of the $\mathrm{d} \rightarrow \mathrm{d}$ transition from red (e.g. [3e $]^{+}, 463$ $\mathrm{nm})$ to blue (e.g. $[30]^{+}, 586 \mathrm{~nm}$ in benzene) giving an additional visual indication of the electronic effect. The $p-\mathrm{NMe}_{2}$ substituent in $[\mathbf{3 o}]^{+}$causes a complex solvatochromic behaviour (Tables S5, S6), where polar solvents result in hypsochromic shift from a blue- to a purple-coloured solution (Figure S20).

The well-resolved ${ }^{1} \mathrm{H},{ }^{13} \mathrm{C}\left\{{ }^{1} \mathrm{H}\right\}$ and ${ }^{31} \mathrm{P}\left\{{ }^{1} \mathrm{H}\right\}$ NMR spectra of $[3]^{+}$and conventional chemical shifts of the resonances are strongly supportive of a diamagnetic $\mathrm{Fe}^{\mathrm{II}}$ oxidation state and a neutral nitroso ligand. Contrary, paramagnetic Fe ${ }^{\mathrm{III}}$ species $[4$ 6] ${ }^{+}$exhibit broadened ${ }^{1} \mathrm{H}$ NMR resonances, and the ${ }^{31} \mathrm{P}\left\{{ }^{1} \mathrm{H}\right\}$ NMR resonances are essentially indistinguishable from the background noise level (ESI). ${ }^{27}$

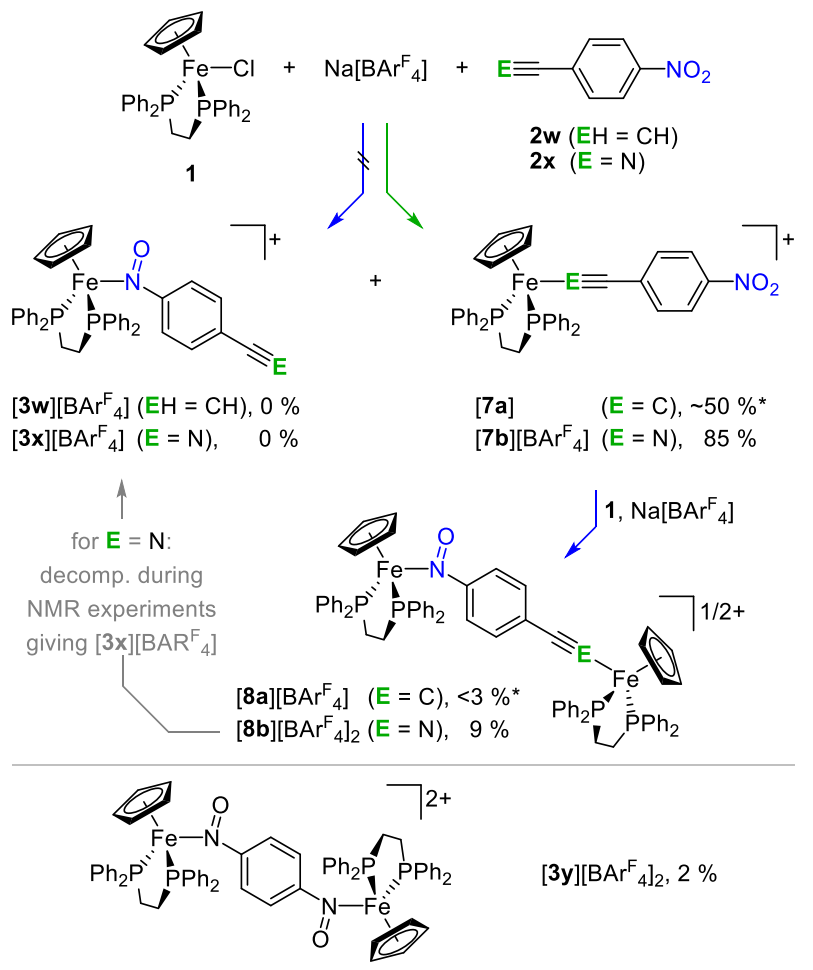

Scheme 3. Reaction of $\mathbf{1}$ with nitroarenes bearing terminal alkynyl (2w) and nitrile (2x) functionalities (top) and synthesis of bimetallic $[\mathbf{3 y}]^{+}$from 1,4-dinitro-benzene (bottom). (Ratio 1 $: \mathrm{Na}\left[\mathrm{BAr}_{4}{ }_{4}\right]: \mathbf{2 m}=5: 5: 1 ;[3 \mathbf{m}]\left[\mathrm{BAr}_{4}{ }_{4}\right](36 \%)$ was also formed. ${ }^{*} \mathrm{KO}^{t} \mathrm{Bu}$ was added prior to the work-up to deprotonate the vinylidene forms.)

However, despite the paramagnetic broadening, the $\mathrm{Cp}$ resonance of $[4]^{+}$was sufficiently well-resolved to allow detection in samples of $[3]^{+}$. Consequently, in cases where full separation of $[3]^{+}$from $[4]^{+}$could not be achieved, an estimate of the yield of the nitroso complex was based on the ratio of the $\mathrm{C}_{5} \mathrm{H}_{5}$ moieties of $[3]^{+}(\sim 4.7 \mathrm{ppm})$ and $[4]^{+}(4.47 \mathrm{ppm})$. The blue, paramagnetic $\mathrm{Fe}^{\mathrm{III}}$ phenolate $[6]^{+}$was characterized by ${ }^{1} \mathrm{H}$ NMR (4.99 ppm, broad, $\left.\mathrm{C}_{5} \mathrm{H}_{5}\right)$ and UV-Vis $\left(\lambda_{\max }=549 \mathrm{~nm}\right.$, blue) spectroscopies, and single crystal $\mathrm{X}$-Ray diffraction (Figure 2). IR bands at 1578 and $1330 \mathrm{~cm}^{-1}$ clearly show the presence of a $\mathrm{NO}_{2}$ functionality in $[6]^{+}$, together with an ether $\tilde{\mathrm{V}}_{\mathrm{C}-\mathrm{O}}$ band at $1261 \mathrm{~cm}^{-1}$ (Table S1). The unsymmetrical dppe backbone in $[\mathbf{5}]^{+}$resulted in two absorption maxima at 519 and $625 \mathrm{~nm}$. The latter is caused by the oxygen donor, giving a blue-coloured solution similar to phenolate $[6]^{+}$. The cationic fragments of $[3-6]^{+}$were also identified by high-resolution mass spectrometry.

By way of example, the electrochemical properties of $[\mathbf{3 k}]^{+}$, $[\mathbf{3 m}]^{+}$and $[\mathbf{3 p}]^{+}$were studied by cyclic voltammetry in dichloromethane solutions, containing $0.05 M\left[\mathrm{NBu}_{4}\right]\left[\mathrm{BAr}{ }_{4}^{\mathrm{Cl}}\right]$ supporting electrolyte. The $p-\mathrm{CH}_{3}$ and $p-\mathrm{NPh}_{2}$ derivatives $[3 \mathbf{k}, \mathbf{p}]^{+}$showed one reversible one-electron redox process at 470 and $-480 \mathrm{mV}$ (vs $\mathrm{FcH} / \mathrm{FcH}^{+}$), respectively. These values are similar to those of $\mathbf{1}(-420 \mathrm{mV})$, and strongly support assignment of the redox wave to an $\mathrm{Fe}^{\mathrm{II} / \mathrm{III}}$ oxidation process. ${ }^{28} \mathrm{In}$ addition, compound $[\mathbf{3 p}]^{+}$exhibits an irreversible oxidation process with an anodic peak potential of $0.52 \mathrm{mV}$, ascribed to the triaryl amine moiety. The $p-\mathrm{NO}_{2}$ derivative $[3 \mathbf{m}]^{+}$showed an irreversible reduction process at $-0.96 \mathrm{mV}$.

To further establish the iron oxidation state in complexes $[3]^{+}$, ${ }^{57} \mathrm{Fe}$ Mössbauer parameters were obtained from $[3 \mathbf{m}, \mathbf{o}]^{+}$by way of example, and compared with those of neutral (1) and cationic $\left.(\mathrm{Fe}(\mathrm{NCPh})(\mathrm{dppe}) \mathrm{Cp}]\left[\mathrm{BAr}_{4}^{\mathrm{Cl}}\right]\right) \mathrm{Fe}^{\mathrm{II}}$, and $\mathrm{Cl}-\left([4]^{+}\right)$and O-functionalized $\left([6]^{+}\right) \mathrm{Fe}^{\text {III }}$ half-sandwich complexes (Table 1. Figure 1). Data were collected at $80 \mathrm{~K}$ and fitted with Lorentzian line shapes by least-squares methods (Figure S2, S15). The isomer shift (I.S.) and quadruple splitting (Q.S.) values of $\mathbf{1}$ and the benzonitrile complex $[\mathrm{Fe}(\mathrm{NCPh})(\mathrm{dppe}) \mathrm{Cp}]\left[\mathrm{BAr}_{4}{ }_{4}\right]$ are consistent with previous measurements, confirming the $\mathrm{Fe}^{\mathrm{II}}$ oxidation state. ${ }^{28}$ The I.S. parameter in $[\mathrm{FeX}(\mathrm{dppe}) \mathrm{Cp}]^{\mathrm{n}+}$ complexes is predominantly affected by the nature of the ligand $\mathrm{X}$, and decreases $\mathrm{O}(0.47)$ $>\mathrm{Cl}(0.42)>\mathrm{NC}(0.36)>\mathrm{N}(\mathrm{O})(0.23 / 0.26)$, while the $s$ electron character at the metal ion increases. ${ }^{29}$

Table 1. ${ }^{57} \mathrm{Fe}$ Mössbauer data for $\mathbf{1},[\mathbf{3 m}]^{+},[\mathbf{4}]^{+},[\mathbf{6}]^{+}$and a Fe ${ }^{\mathrm{II}}$ benzonitrile complex in comparison with literature.

\begin{tabular}{|c|c|c|c|}
\hline Compound & I.S. $(\mathrm{mm} / \mathrm{s})$ & $\begin{array}{l}\text { Q.S. } \\
(\mathrm{mm} / \mathrm{s})\end{array}$ & $\Gamma(\mathrm{mm} / \mathrm{s})$ \\
\hline 1 & $0.430(3)$ & $1.903(5)$ & $0.128(4)$ \\
\hline $\mathbf{1}^{28}$ & 0.44 & 1.92 & 0.13 \\
\hline$[3 \mathrm{~m}]^{+}$ & $0.228(9)$ & $0.845(16)$ & $0.174(12)$ \\
\hline$[30]^{+}$ & $0.257(5)$ & $1.113(10)$ & $0.155(7)$ \\
\hline$[4]^{+}$ & $0.419(17)$ & $0.76(3)$ & $0.27(3)$ \\
\hline$[4(\mathrm{~F})]^{+, \mathrm{a})}$ & 0.426 & 0.92 & n.r. \\
\hline$[6]^{+}$ & $0.47(5)$ & $0.82(8)$ & $0.44(8)$ \\
\hline$[\mathrm{Fe}(\mathrm{NCPh})(\mathrm{dppe}) \mathrm{Cp}]^{+}$ & $0.356(3)$ & $1.932(7)$ & $0.120(6)$ \\
\hline${ }_{28}\left[\mathrm{Fe}\left(\mathrm{NCCH}_{3}\right)(\mathrm{dppe}) \mathrm{Cp}\right]^{+}$ & 0.39 & 2.01 & 0.14 \\
\hline
\end{tabular}

a) Value of the fluoride derivative of $[4]^{+}$taken from Ref 30 . n.r. = not reported. 
In case of nitroso complexes $[3 \mathbf{m}, \mathbf{o}]^{+}$the substantial metal-toligand $d, p$-backbonding, increases the amount of $s$-electron density at the metal indirectly, resulting in I.S. values similar to those recently reported for the $\mathrm{Fe}^{\mathrm{II}}$ hydride complex $\left[\mathrm{FeH}(\mathrm{dppe}) \mathrm{Cp}^{*}\right]^{27,31}$, and significantly lower than the $\mathrm{Fe}^{\mathrm{III}}$ compounds $[4]^{+}$and $[6]^{+}$. Indeed, comparison of $\mathrm{Fe}^{\mathrm{II}}$ and $\mathrm{Fe}^{\mathrm{III}}$ chlorides $\mathbf{1}$ and $[4]^{+}$also reveals that the I.S. value in these half-sandwich complexes are rather insensitive to the iron oxidation state. This can be explained by the equilibrating donor/back-bonding effects of the Fe-Cp interaction, and the not insignificant ligand-character involved the oxidation of $1 .^{29}$ The Q.S. parameter decreases from 1 to $[4]^{+}$, revealing a more symmetric charge distribution in the oxidised complex $[4]^{+}$. Similarly low values are found for $\mathrm{Fe}^{\mathrm{III}}$ phenolate $[6]^{+}$. The Q.S. value is also affected by the electronic properties of the para-substituent in nitroso complexes $[3]^{+}$. Exchange of a $p$ $\mathrm{NO}_{2}$ group in $[\mathbf{3 m}]^{+}$by $p-\mathrm{NMe}_{2}$ in $[3 \mathbf{3 o}]^{+}$increases the Q.S. from $0.845(16)$ to $1.113(10)$, caused by the reduced $\pi$-acidity of the ligand in $[3 \mathbf{3 o}]^{+}$, resulting in a more asymmetric charge distribution around the metal.

Although both values are similar to those of $\mathrm{Fe}^{\mathrm{III}}$ complexes $[4]^{+}$and $[6]^{+}$, the sharp signals in NMR experiments reveal a diamagnetic $\mathrm{Fe}^{\mathrm{II}}$ configuration for the nitroso complexes. Clearly the Q.S. are sensitive to both the nature of the ligand environment and oxidation state of the metal ion. The halfheight width (line broadening, $\Gamma$ ) increases from $\mathrm{Fe}^{\mathrm{II}}(0.13)<$ $[30]^{+}(0.16) \approx[3 \mathrm{~m}]^{+}(0.17)<\mathrm{Fe}$ III $-\mathrm{Cl}(0.27)<\mathrm{Fe}^{\mathrm{III}}-\mathrm{O}(0.44)$. Thus, although comparison of complexes with ligands of different nature can be misleading, ${ }^{31} \Gamma$ reveals that nitroso complexes $[\mathbf{3 m}, \mathbf{o}]^{+}$exhibit similar properties to those of other $\mathrm{Fe}^{\mathrm{II}}$ compounds, evidencing a $\mathrm{Fe}^{\mathrm{II}} / \mathrm{N}(\mathrm{O}) \mathrm{R}^{0}$ metal/ligand couple.

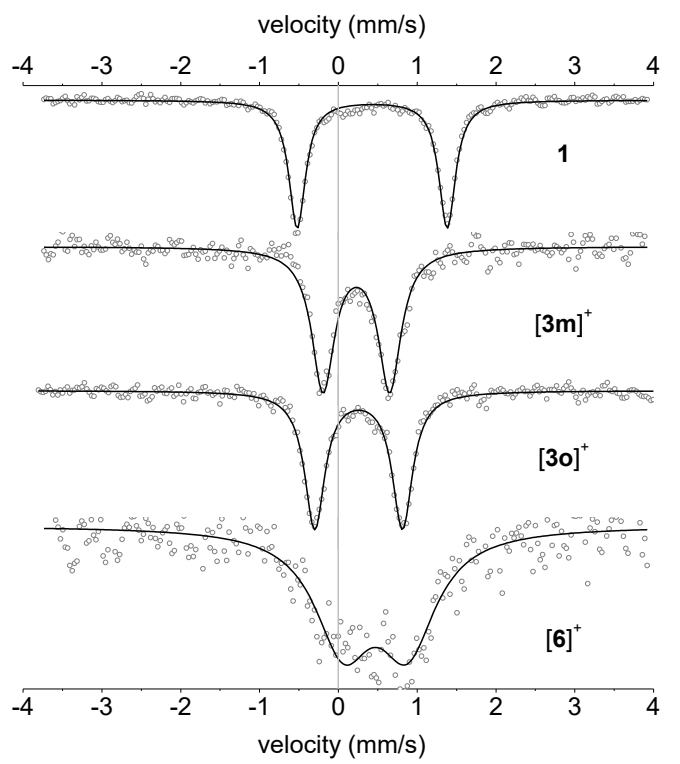

Figure 1. ${ }^{57} \mathrm{Fe}$ Mössbauer spectra of $\mathbf{1},[\mathbf{3 m}]^{+},[\mathbf{3 o}]^{+}$, and $[\mathbf{6}]^{+}$.
Compounds $[\mathbf{3 d}, \mathbf{m}, \mathbf{o , s}]^{+},[\mathbf{4}]^{+},[\mathbf{5}]^{+},[\mathbf{6}]^{+}$and $[\mathbf{9}]^{2+}\left([\mathbf{9}]^{2+}=\right.$ $\left[\{\mathrm{Fe}(\mathrm{dppe}) \mathrm{Cp}\}_{2}(\mu \text {-dppe })\right]^{2+}$, Figures 2 and $\left.\mathrm{S} 1-5\right)$ could further be characterised by single crystal $\mathrm{X}$-ray diffraction. The Fe-P distances (Table 2) in $[\mathbf{3 d}, \mathbf{m}, \mathbf{o}, \mathbf{s}]^{+}$are comparable to other $\mathrm{Fe}$ nitroso complexes, ${ }^{19}$ and cationic, N-ligated complexes, such as $[\mathrm{Fe}(\mathrm{NCMe})(\mathrm{dppe}) \mathrm{Cp}]^{+}$(Figure $\mathrm{S} 8$ ), which further supports the description of compounds $[3]^{+}$in terms of a $\mathrm{Fe}^{\mathrm{II}}$ metal atom and a neutral nitroso ligand.

The $\mathrm{Fe}-\mathrm{N}$ and $\mathrm{N}-\mathrm{O}$ bond lengths are in good agreement with those of Fe porphyrin nitroso complexes featuring a low-spin $\mathrm{Fe}^{\mathrm{II}}$ centre. $^{10}$ The $\mathrm{N}-\mathrm{O}$ distances of $[\mathbf{3 d}, \mathbf{m}, \mathbf{o}, \mathbf{s}]^{+}(1.251(3)$ 1.272(12) ^), featuring more electron-donating dppe ancillary ligands, are slightly elongated relative to the carbonyl complex $\left[\mathrm{Fe}\{\mathrm{N}(\mathrm{O})-\mathrm{Ph}\}(\mathrm{CO})_{2} \mathrm{Cp}\right]^{+}(1.226(3) \AA),{ }^{18}$ indicating greater $\mathrm{Fe}-$ $\mathrm{N}(\mathrm{O})$ back bonding. The $\mathrm{Fe}-\mathrm{O}=\mathrm{NR}$ binding mode was not observed in any of the compounds studied here. ${ }^{8}$ The donoracceptor electronic effects observed in the NMR and optical properties are also reflected in the $\mathrm{C}-\mathrm{N}$ bond lengths towards the para substituents, which decrease from 1.465(3) $\left(p-[\mathbf{3 m}]^{+}\right.$, $\left.\mathrm{NO}_{2}\right)$ to $1.363(4)\left(p-[\mathbf{3 o}]^{+}, \mathrm{NMe}_{2}\right) \AA$.

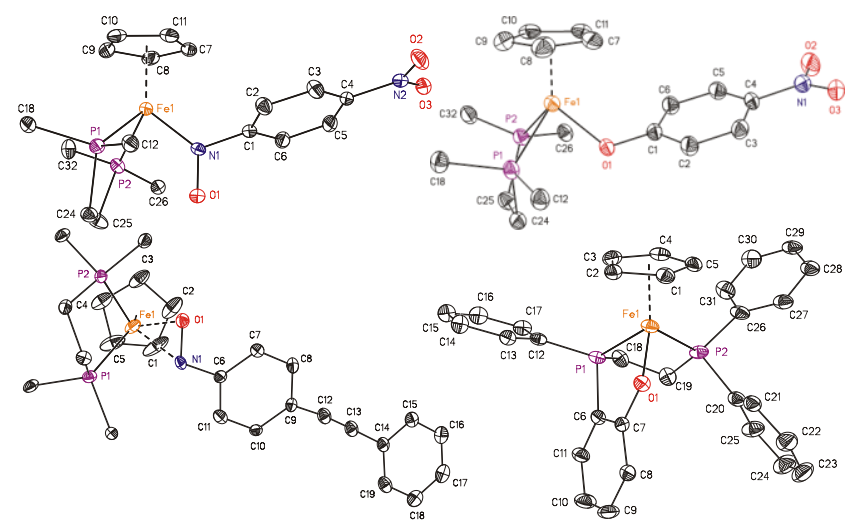

Figure 2. ORTEP drawings of the molecular structures of $[3 \mathbf{m}]^{+}\left(\right.$top left $\left.{ }^{[\mathrm{a}]}\right),[6]^{+}\left(\right.$top right $\left.{ }^{[\mathrm{b}]}\right),[3 \mathrm{~s}]^{+}\left(\right.$bottom left $\left.{ }^{[\mathrm{b}]}\right)$, and $[5]^{+}$(bottom right ${ }^{[\mathrm{a}]}$ ) showing their atom numbering scheme. $\mathrm{H}$ atoms, the $\left[\mathrm{BAr}_{4}{ }_{4}\right]^{-}(\mathbf{3 m}, \mathbf{s}, \mathbf{5})$ or $\left[\mathrm{BAr}_{4}^{\mathrm{Cl}}\right]^{-}(\mathbf{3 s})$ counter ion, disordered parts (see ESI) and the phenyl rings of the dppe fragments have been omitted for clarity. Selected bond properties are summarized in Table 2. (Probability levels: [a], $30 \%$; [b], $50 \%$.) Selected bond properties: [5] $]^{+}, \mathrm{Fe}-\mathrm{P}$ 2.154(9)2.2757(7), Fe-O 1.863(2), Fe-Ct $\mathrm{Ct}_{\mathrm{Cp}}$ 1.7355(4); [6] ${ }^{+}, \mathrm{Fe} 1-\mathrm{P} 1$ 2.2460(8), Fe1-P2 2.2589(8), Fe-O 1.8828(18), C-N 1.457(3), N-O 1.228(3) and 1.233(3), Fe- $\mathrm{Ct}_{\mathrm{Cp}}$ 1.7495(4). For a comparison of bond parameters of nitroso complexes $[3]^{+}$, see Table 2.

The strength of the $\mathrm{Fe}-\mathrm{N}$ interaction in the nitroso complexes was investigated by displacement reactions with acetonitrile. Complexes [3m] $\left[\mathrm{BAr}_{4}{ }_{4}\right]\left(p-\mathrm{NO}_{2}\right)$ and [3o] $\left[\mathrm{BAr}_{4}{ }_{4}\right]\left(p-\mathrm{NMe}_{2}\right)$, representing both extremes of the electronic scale, were chosen by way of example. Electron-poor $[\mathbf{3 m}]^{+}$displayed a high barrier towards displacement of the nitroso ligand, and converted only slowly to the acetonitrile complex $[\mathrm{Fe}(\mathrm{NCMe})(\mathrm{dppe}) \mathrm{Cp}]^{+}$in refluxing $\mathrm{NCMe}$, with $10 \%$ conversion after $4 \mathrm{~h}$, and $[\mathbf{3 m}]^{+}$being recovered in $90 \%$. Reaction 
for $12 \mathrm{~h}$ gave $\sim 63 \%$ conversion (Figure S19), demonstrating the high stability of $[\mathbf{3 m}]^{+}$. In addition, it should be noted that 1,4-dinitrobenzene was also formed in this reaction, by reoxidation of the released $p$-nitroso nitrobenzene ligand. In contrast, the blue colour of electron-rich $[30]^{+}$vanishes completely within 10 to 20 minutes in acetonitrile at ambient temperature. These results also help explain the lower yields of the electron-rich nitroso complexes $[\mathbf{3 h}, \mathbf{o}, \mathbf{p}]^{+}$(Scheme 2), which are more prone towards a release of the nitroso ligand during the work-up and purification process.

Table 2. Selected bond properties $\left(\AA /^{\circ}\right)$ of nitroso complexes $[\mathbf{3 d}, \mathbf{m}, \mathbf{o}, \mathbf{s}]^{+}$.

\begin{tabular}{|c|c|c|c|c|}
\hline Compd. & {$[\mathbf{3 d}]^{+[\mathrm{a}]}$} & {$[3 \mathrm{~m}]^{+}$} & {$[30]^{+}$} & {$[3 \mathbf{s}]^{+}$} \\
\hline $\mathrm{R}$ & $p-\mathrm{Br}$ & $p-\mathrm{NO}_{2}$ & $p-\mathrm{NMe}_{2}$ & $p-\mathrm{C} \equiv \mathrm{CPh}$ \\
\hline$\eta^{1} / \eta^{2}$ & $100 / 0$ & $90.5 / 9.5$ & $100 / 0$ & $47.8 / 52.2$ \\
\hline$\overline{\mathrm{Fe}-\mathrm{Ct}}$ & $\begin{array}{l}.7517(3)- \\
1.7578(3)\end{array}$ & 1.7493(4) & $1.7498(4)$ & $1.7351(5)$ \\
\hline $\mathrm{Fe}-\mathrm{P}$ & $2.2186(7)-$ & $2.2279(8)$ & $2.2309(9)$ & $\begin{array}{l}2.2345(12) \\
2.2538(10)\end{array}$ \\
\hline $\mathrm{Fe}-\mathrm{N}$ & $\begin{array}{l}2.2453(6) \\
1.835(2) \\
1.827(2)\end{array}$ & $\begin{array}{l}2.2234(8) \\
1.820(2)\end{array}$ & $\begin{array}{l}2.2361(9) \\
1.841(3)\end{array}$ & $\begin{array}{l}2.2538(10) \\
1.707(9)\left(\eta^{1}\right) \\
2.132(7)\left(n^{2}\right)\end{array}$ \\
\hline $\mathrm{Fe}-\mathrm{O}^{[\mathrm{b}]}$ & $\begin{array}{l}2.7289(17) \\
2.7424(17)\end{array}$ & $\begin{array}{l}2.740(2) \\
2.114(19)\end{array}$ & $2.712(2)$ & $\begin{array}{l}2.632(2)\left(\eta^{1}\right) \\
2.108(5)\left(\eta^{2}\right)\end{array}$ \\
\hline $\mathrm{N}-\mathrm{O}=\mathrm{N}=\mathrm{O}$ & $\begin{array}{l}1.267(3) \\
1.252(3)\end{array}$ & $1.255(3)$ & $1.251(3)$ & $\begin{array}{l}1.272(12) \\
\left(\eta^{1}\right) \\
1.323(10) \\
\left(\eta^{2}\right)\end{array}$ \\
\hline $\mathrm{N}-\mathrm{C}_{\mathrm{N}=\mathrm{O}}$ & $\begin{array}{l}1.452(3) \\
1.471(3)\end{array}$ & $1.459(3)$ & $1.457(4)$ & $1.452(5)$ \\
\hline $\mathrm{C}-\mathrm{N}-\mathrm{O}$ & $\begin{array}{l}111.16(19) \\
111.55(19)\end{array}$ & $110.51(19)$ & $112.4(2)$ & $\begin{array}{l}109.7(8)\left(\eta^{1}\right) \\
111.9(6)\left(\eta^{2}\right)\end{array}$ \\
\hline $\mathrm{Fe}-\mathrm{N}-\mathrm{O}$ & $\begin{array}{l}122.12(16) \\
124.89(17)\end{array}$ & $125.02(17)$ & $123.0(2)$ & $\begin{array}{l}123.5(6)\left(\eta^{1}\right) \\
70.8(4)\left(\eta^{2}\right)\end{array}$ \\
\hline $\begin{array}{l}\mathrm{C}_{6-} \\
\mathrm{N}=\mathrm{O}^{[\mathrm{c}]}\end{array}$ & $\begin{array}{l}49.00(14) \\
54.29(14)\end{array}$ & $\begin{array}{l}66.58(14) \\
\left(\eta^{1}\right) \\
7(2)\left(\eta^{2}\right)\end{array}$ & $47.9(2)$ & $\begin{array}{l}61.0(7)\left(\eta^{1}\right) \\
15.7(9)\left(\eta^{2}\right)\end{array}$ \\
\hline $\mathrm{N}-\mathrm{O}_{\mathrm{NO} 2}$ & & $\begin{array}{l}1.216(3) \\
1.225(3)\end{array}$ & 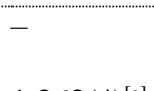 & - \\
\hline $\mathrm{N}-\mathrm{C}_{\mathrm{NX} 2}$ & & $1.465(3)^{[\mathrm{d}]}$ & $1.363(4)^{[\mathrm{e}]}$ & - \\
\hline
\end{tabular}

[a] Two molecules in the asymmetric unit, consistently ordered values. [b] Grey: non-bonding distance. [c] Plane intersection. [d] $\mathrm{X}=\mathrm{O}$. [e] $\mathrm{X}=\mathrm{CH}_{3}$. The $9.5 \%$ of $\eta^{2}$ coordination in $[\mathbf{3 m}]^{+}$are not discussed, due to the lower precision of the data, except noted.

The electronic differences of the nitroso ligand substituent are also reflected in the $\mathrm{Fe}-\mathrm{N}$ distances and degree of $\eta^{1} / \eta^{2}$ disorder in the solid state structures. The more labile $p-\mathrm{NMe}_{2}$ derivative, $[30]^{+}$, offers a relatively long $\mathrm{Fe}-\mathrm{N}$ distance (1.841(3) $\AA$ ) and absence of the $\eta^{2}$-coordination mode of the $\mathrm{N}(\mathrm{O}) \mathrm{R}$ moiety in the structural model, consistent with limited $\mathrm{Fe}-\mathrm{N}$ back bonding. The derivatives bearing more electron withdrawing $p-\mathrm{NO}_{2}\left([\mathbf{3 m}]^{+}\right)$and $p-\mathrm{C} \equiv \mathrm{CPh}\left([\mathbf{3 s}]^{+}\right)$moieties offer shorter $\mathrm{Fe}-\eta^{1}-\mathrm{N}(\mathrm{O})$ distances (1.820(2), 1.707(9) $\AA$, respectively) and feature more significant contributions from the disordered $\eta^{2}-\mathrm{N}(\mathrm{O})$ component in the structural models $\left([3 \mathrm{~m}]^{+}, 10 \%\right.$; $\left.[3 \mathbf{s}]^{+}, 52 \%\right)$. The $\mathrm{C}_{6}-\mathrm{N}=\mathrm{O}$ torsion angle of the $\eta^{1}$-bonded nitroso functionality towards the phenyl plane follows the trend of an decrease of electron density in $[\mathbf{3 o}]^{+}>$ $[3 \mathrm{~s}]^{+}>[3 \mathrm{~m}]^{+}$via $47.9(2)<61.0(7)<66.58(14)^{\circ}$. The $\eta^{2}$ coordination mode induces a rather coplanar orientation of the $\mathrm{NO}$ and phenyl fragments (Table 2). The $\mathrm{Fe}-\mathrm{O}$ distances decrease from $\sim 2.7\left(\eta^{1}\right.$-entities $)>\sim 2.1\left(\eta^{2}\right.$-entities $)>\sim 1.87 \AA$ for phenolate complexes $[\mathbf{5}]^{+}$and $[\mathbf{6}]^{+}$.

Recent investigations by Ishii and co-workers highlighted the use of $\mathrm{Na}\left[\mathrm{BAr}_{4}{ }_{4}\right]$ for the activation of $\mathbf{1}$ by halide abstraction in non-polar / non-coordinating solvents and in the presence of the weakly coordinating borate anion. The electronically and co-ordinatively unsaturated $[\mathrm{Fe}(\mathrm{dppe}) \mathrm{Cp}]^{+}$complex is able to activate internal alkynes via an alkyne-vinylidene rearrangement. $^{21}$ Other halide abstracting agents such as $\mathrm{AgPF}_{6}$ or $\mathrm{NaBPh}_{4}$ resulted in a complex mixture of products. However, the use of $\left[\mathrm{BAr}_{4}{ }_{4}\right]^{-}$is not without difficulty, for its e.g. rather elaborative purification and the high propensity for disorder of the $\mathrm{CF}_{3}$ groups in solid state, ${ }^{32}$ which can complicate crystallisation processes.

To address some of these potential concerns, the nonfluorinated, but still weakly coordinating, $\left[\mathrm{B}\left(3,5-\mathrm{Cl}_{2}-\mathrm{C}_{6} \mathrm{H}_{3}\right)_{4}\right]^{-}$ anion was explored in these studies. ${ }^{32}$ Comparison between reactions promoted by the more soluble $\mathrm{Na}\left[\mathrm{BAr}_{4}{ }_{4}\right]$ salt, and $\mathrm{Na}\left[\mathrm{BAr}_{4}\right]^{-}$gave similar product distributions, but often with higher yields of the key compounds $[3]^{+}$from the fluorinated salt. For example, in the case of $\left([\mathbf{3 b}, \mathbf{m}]^{+}\right)$the $\left[\mathrm{BAr}_{4}^{\mathrm{F}}\right]^{-}$counter ion significantly enhances the yield of the products $[\mathbf{3 b}, \mathbf{m}]\left[\mathrm{BAr}_{4}{ }_{4}\right]$ vs $[\mathbf{3 b}, \mathbf{m}]\left[\mathrm{BAr}_{4}{ }_{4}\right]$ (Scheme 2), which might either be due to a better solubility of fluorinated counter ions in general, or the lower amount of water in the respective sodium salt (see ESI). Nevertheless, many of the resulting products are difficult to crystallise or precipitate using $\left[\mathrm{BAr}_{4}^{\mathrm{F}}\right]^{-}$, whereas the chlorinated version readily gave many of the products as solid materials. ${ }^{32}$

The formation of the $\mathrm{Fe}^{\mathrm{III}}$ by-product $[4]^{+}$is unlikely to be due to oxidation of $\mathbf{1}$ by the nitroarenes given the increased yields of complexes $[\mathbf{3}]^{+}$in excess nitroarene. Furthermore, reaction of $\mathbf{1}$ with the nitroso derivative of $\mathbf{2 0}$, which is an even stronger electron acceptor $\left(\sigma_{\mathrm{p}}(\mathrm{NO})=0.91 ; \sigma_{\mathrm{p}}\left(\mathrm{NO}_{2}\right)=0.78\right)^{26}$ and would consequently facilitate an electron transfer, did not result in $[4]^{+}$but rather gave [3o] $\left[\mathrm{BAr}_{4}^{\mathrm{F}}\right]$ in $89 \%$ yield (Scheme 2). Rather, the formation of $[4]^{+}$can be attributed to reaction of $\{\mathrm{Fe}(\mathrm{dppe}) \mathrm{Cp}\}^{+}$with dichloromethane. ${ }^{31}$ The further byproduct $[\mathbf{5}]^{+}$(Scheme 2, Figure 2) was obtained as a blue solid in various quantities (usually $<10 \%$ ). Compound $[5]^{+}$most probably originates by abstraction of an oxygen atom from the nitro substrate and subsequent internal rearrangement (see Scheme 4 below).

A further feature of the reaction is the rapid colour change from dark to intense blue upon the addition of the borate salts $\mathrm{Na}\left[\mathrm{BAr}^{\mathrm{X}}{ }_{4}\right]$ to the mixtures of $\mathbf{1}$ and $\mathbf{2}$. Reactions of $\mathbf{1}$ and $\mathrm{Na}\left[\mathrm{BAr}_{4}{ }_{4}\right]$ in the absence of nitro compounds, e.g, upon addi- 
tion of toluene, diphenylacetylene or $N, N$-dimethylaniline instead, did not show such behaviour, nor has such a distinctive colour change been reported for similar halide abstraction reactions of [FeX(dppe)Cp'] complexes carried out in different solvents or mediated by other reagents. ${ }^{33,34}$ Several attempts, e.g. within the formation of $[\mathbf{3 b}, \mathbf{d}, \mathbf{s}]^{+}$, were carried out to isolate or crystallize this first formed, highly air-sensitive blue species, which appears to be stable for only a few hours in solution judging by the discharge of the characteristic colour. To date, the blue species formed en route to e.g. $[\mathbf{3 b}, \mathbf{d}, \mathbf{s}]^{+}$ have resulted in oily precipitates, containing small quantities of orange crystals, identified via single crystal X-ray diffraction as the bimetallic complex $\left.[9]\left[\mathrm{BAr}^{\mathrm{Cl}}\right]_{2}\right]_{2} \quad=$ $\left[\{\mathrm{Fe}(\mathrm{dppe}) \mathrm{Cp}\}_{2}(\mu \text {-dppe })\right]^{2+}$; Figure S5). The additional bridging dppe ligand within $[9]^{2+}$ evinces decomposition of the precursor complex. In addition to [9] ${ }^{2+}$, varying amounts of the $\mathrm{Fe}^{\mathrm{III}}$ species $\left[\mathbf{4}^{+}\right.$were also obtained from the attempts to isolate the key blue intermediates in these reactions.

The sole nitroarene that resulted in a stable blue-coloured solution at ambient temperature on reaction with $\mathbf{1}$ and $\mathrm{Na}\left[\mathrm{BAr}_{4}{ }_{4}\right]$ was 1-fluoro-2-nitrobenzene $2 \mathbf{r}$ (Scheme 4). This blue-coloured compound was identified as $[\mathbf{C}]^{2+}$ by NMR, IR and UV-Vis spectroscopies (Table S3, Figures S13, S14 and $\mathrm{S} 8$, respectively). The intense blue colour of $[\mathbf{C}]^{2+}\left(\lambda_{\max }=695\right.$ $\mathrm{nm}$ ) is consistent with the presence of an $\mathrm{Fe}-\mathrm{O}$ bond (Tables S2,S3), also observed for phenolates $[\mathbf{5}]^{+}$and $[\mathbf{6}]^{+}$, and is $>100$ $\mathrm{nm}$ shifted to lower energy than the primary absorption band in $1(588 \mathrm{~nm})$. The $\eta^{6} / \pi$-coordinated complex $\left[\mathrm{Fe}\left(\eta^{6}-\right.\right.$ $\left.\left.\mathrm{C}_{6} \mathrm{H}_{5} \mathrm{Me}\right)(\mathrm{dppe}) \mathrm{Cp}\right]^{+}$is not responsible for this colour. ${ }^{35}$ The bimetallic nature of $[\mathbf{C}]^{2+}$ was confirmed by complete conversion of $\mathbf{1}$ to $[\mathbf{C}]^{2+}$ following a reaction with 0.5 equiv of $\mathbf{2 r}$ over $30 \mathrm{~min}$ at $60{ }^{\circ} \mathrm{C}$ (Figure S13). Allowing the reaction to proceed for 18 hours at $70{ }^{\circ} \mathrm{C}$ gave $[3 \mathrm{r}]\left[\mathrm{BAr}_{4}{ }_{4}\right]$ in $50 \%$ yield; if two molecules of $\mathbf{1}$ are considered to produce $[\mathbf{3 r}]^{+}$then the yield is quantitative (Schemes 2,4). The suggestion of a bimetallic structure for $[\mathbf{C}]^{2+}$ is further supported by the IR spectrum of this complex, with both asymmetric and symmetric $\tilde{\mathrm{v}}\left(\mathrm{NO}_{2}\right)$ stretching vibrations shifted towards lower energy by 7 and $12 \mathrm{~cm}^{-1}$ when compared with the free nitroarene $2 \mathbf{r}$ (Table S1, Figure S13), indicating that the nitro functionality acts as a donor ligand, and the overall symmetry of the $\mathrm{NO}_{2}$ group is retained, excluding the presence of monometallic $[\mathbf{B}]^{+}$.

The ${ }^{31} \mathrm{P}\left\{{ }^{1} \mathrm{H}\right\}$ NMR of $[\mathbf{C}]^{2+}$ showed one singlet at $98.5 \mathrm{ppm}$ and a small signal at $97.3 \mathrm{ppm}(<10 \%)$, which can be ascribed to traces of product $[\mathbf{3 r}]^{+}(97.3 \mathrm{ppm})$ (Table S3). A further indicative parameter for a complete conversion of $\mathbf{1}$ into $[\mathbf{C}]^{2+}$ is the ${ }^{13} \mathrm{C}\left\{{ }^{1} \mathrm{H}\right\}$ NMR resonance of the $\mathrm{Cp}$ moiety, which progressively moves to lower-field from $76.9<84.1<$ $90.3 \mathrm{ppm}$ during conversion of $\mathbf{1}$ to $[\mathbf{C}]^{2+}$ and $[\mathbf{3 r}]^{+}$. The ${ }^{13} \mathrm{C}\left\{{ }^{1} \mathrm{H}\right\}$ NMR signals of the 1-fluoro-2-nitro-benzene entity in $[\mathbf{C}]^{2+}$ are also easily distinguished from those of $\mathbf{2 r}$ and $[3 \mathbf{r}]^{+}$. The $\mathrm{C}-\mathrm{NO}_{2}$ carbon resonance is shifts to significantly lowerfield on reaction from $137.62(\mathbf{2 r})$ to $137.94\left([\mathbf{C}]^{2+}\right)$, supporting the presumption that both $\mathrm{NO}_{2}$ oxygen atoms act as donor atoms and therefore reduce the electron density at the bonded $\mathrm{C}$ atom (Figure S12). However, the $\mathrm{C}-\mathrm{F}$ probe does not undergo significant changes, neither in the ${ }^{19} \mathrm{~F}$ NMR, where $2 \mathbf{r}$ and $[\mathbf{C}]^{2+}$ both show a signal at $-118.0 \mathrm{ppm}$, nor within the ${ }^{13} \mathrm{C}\left\{{ }^{1} \mathrm{H}\right\}$ NMR (C-F, 2r: $\left.155.6 \mathrm{ppm} ;[\mathbf{C}]^{2+}: 155.5 \mathrm{ppm}\right)$, and small changes of the ${ }^{1} J_{\mathrm{C}, \mathrm{F}}$ coupling constants of $263.9 \mathrm{~Hz}(\mathbf{2 r})$ and $265.6 \mathrm{~Hz}\left([\mathbf{C}]^{2+}\right)$. The conversion from the putative $\mu_{2^{-}}$ $\mathrm{NO}_{2}$ mode in $[\mathbf{C}]^{2+}$ to the NO ligand in $[3 \mathbf{r}]^{+}$gives rise to diagnostic changes in the NMR resonances which shifts from 118.0 to -123.4 ppm $\left({ }^{19} \mathrm{~F}\right.$ NMR $), 137.94$ to $159.2\left({ }^{13} \mathrm{C}\left\{{ }^{1} \mathrm{H}\right\}\right.$ NMR, C-NO, $\left.{ }^{2} J_{\mathrm{C}, \mathrm{F}}=12.2 \mathrm{~Hz}\right)$ and 155.5 to $149.9 \mathrm{ppm}(\mathrm{C}-\mathrm{F}$, ${ }^{1} J_{\mathrm{C}, \mathrm{F}}=252.2 \mathrm{~Hz}$, Table S3) on completion of the reaction. The $\mathrm{d} \rightarrow \mathrm{d}$ transition shifts from $695[\mathbf{C}]^{+}$to a value found for other examples of the orange/red nitroso complexes $[3]^{+}\left(\lambda_{d \rightarrow d}<470\right.$ $\mathrm{nm})$, as well as $\left[\mathrm{Fe}(\mathrm{dppe}) \mathrm{Cp}^{*}\right]^{+31}$ and $\left[\mathrm{Fe}(\mathrm{CO})_{2}\left(\mathrm{O}_{2} \mathrm{NPh}\right) \mathrm{Cp}\right]^{+}$ $(\lambda \sim 430 \mathrm{~nm}) .{ }^{28,34}$ With these various pieces of evidence in hand, a mechanism for the formation of $[3]^{+}$and $[5]^{+}$may be proposed (Scheme 3). Precursor $\mathbf{1}$ is activated by chloride abstraction with forming low-valent $[\mathbf{A}]^{+}$, which is readily coordinated by an oxygen atom of the nitroarene substrate.

Although, an excess of $\mathbf{2}$ helps to capture $[\mathbf{A}]^{+}$and shift the equilibrium towards monometallic $[\mathbf{B}]^{+}$, bimetallic $[\mathbf{C}]^{2+}$ is considered as the key species, due to the maintained symmetry of the $\tilde{v}\left(\mathrm{NO}_{2}\right)$ stretching vibrations in the IR spectrum (Figure S14). Bimetallic $[\mathbf{C}]^{2+}$ undergoes a homolytic $\mathrm{N} \ldots \mathrm{O}$ bond cleavage and dissociates into nitroso complex $[3 \mathbf{r}]^{+}$, with formal $\mathrm{N}^{\mathrm{III}} \rightarrow \mathrm{N}^{\mathrm{I}}$ reduction, and formation of the oxoiron species $[D]^{+}$, containing a $\left\{\mathrm{Fe}^{\mathrm{IV}}=\mathrm{O}\right\}$ entity commonly found in oxoiron $^{\text {IV }}$ heme complexes. ${ }^{36,36}$ This mechanism is supported by recent computational studies, suggesting that oxygen can be removed from the $\mathrm{N}^{+}-\mathrm{O}^{-}$entity in pyridine- $N$-oxides by iron half-sandwich complexes $\left[\mathrm{Fe}^{\mathrm{II}}\left(\mathrm{O} \leftarrow \mathrm{NC}_{5} \mathrm{H}_{5}\right) \mathrm{Ph}(\mathrm{L}) \mathrm{Cp} *\right] \quad(\mathrm{L}=$ $\mathrm{CO}, \mathrm{Cl}, \mathrm{NMe}_{2}$, etc. $) .{ }^{37}$

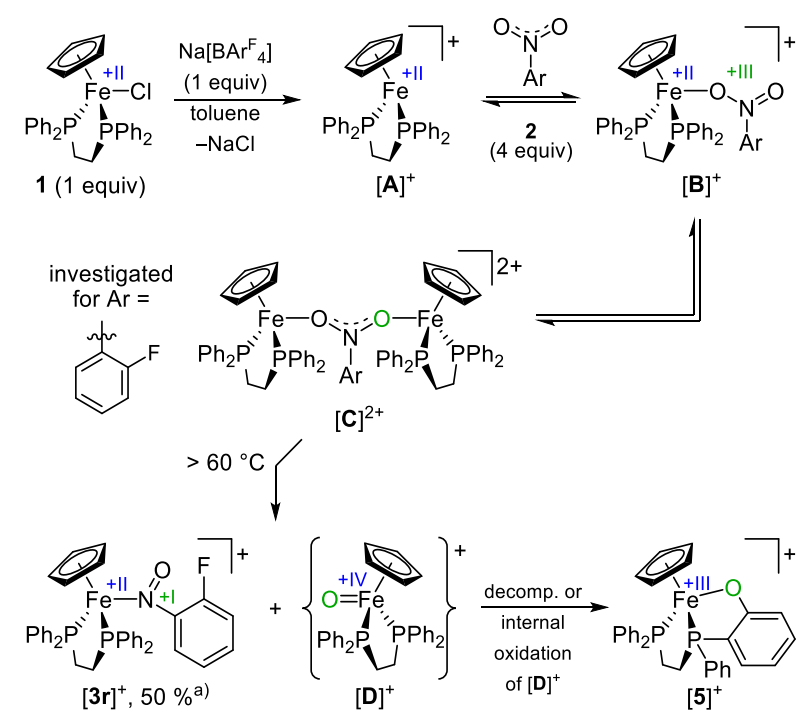

Scheme 4. Proposed mechanism for the synthesis of $o$-fluorosubstituted complex $[\mathbf{3 r}]^{+}$via intermediates $[\mathbf{A}-\mathbf{C}]^{+/ 2+}$. (Yield based on $\mathbf{1}$, considering 2 equiv of $\mathbf{1}$ for the formation of $[3 r]\left[\mathrm{BAr}_{4}{ }^{\mathrm{F}}\right]$, according to the proposed mechanism) 
The computational model indicates that the $\mathrm{N}-\mathrm{O}$ bond is cleaved forming a $\mathrm{Fe}^{\mathrm{IV}}=\mathrm{O}$ or $\mathrm{Fe}^{\mathrm{III}}-\mathrm{O}^{\cdot-}$ intermediate with concomitant release of pyridine. The abstracted oxygen is subsequently inserted into the $\mathrm{Fe}-\mathrm{Ph}$ bond, forming the phenolate ligand. In the case of reactions described here, a similar process would allow the $\mathrm{N}-\mathrm{O}$ cleavage product derived from $[\mathbf{C}]^{2+}$ to be captured as the nitroso complex $[3]^{+}$, together with the formation of the $\mathrm{Fe}^{\mathrm{IV}}=\mathrm{O}$ species $[\mathbf{D}]^{+}$. An internal $\mathrm{C}, \mathrm{H}$ activation process of $[\mathbf{D}]^{+}$gives $[\mathbf{5}]^{+}$, whereby one of the adjacent phenyl groups of the dppe ligand is oxidized at its ortho position. This process requires a reaction temperature of $60{ }^{\circ} \mathrm{C}$ and does not occur at ambient conditions. It also competes with a decomposition process of $[\mathbf{D}]^{+}$, resulting in small amounts of $[\mathrm{FcH}]^{+}(\mathrm{ESI})$ and insoluble material remaining on top of a column. The hydrogen radical formed during this internal oxidation process is most probably consumed by one of the formed by-products.

\section{CONCLUSION}

Activation of the iron half-sandwich complex [ $\mathrm{FeCl}(\mathrm{dppe}) \mathrm{Cp}]$ (1) by chloride abstraction with $\mathrm{Na}\left[\mathrm{BAr}^{\mathrm{X}}{ }_{4}\right]$ in toluene permits reaction with a range of common nitro aromatics to give cationic iron nitroso complexes $\left[\mathrm{Fe}\left\{\mathrm{N}(\mathrm{O})-\mathrm{C}_{6} \mathrm{H}_{4} \mathrm{R}\right\}(\mathrm{dppe}) \mathrm{Cp}\right]^{+}$ $\left([3]^{+}\right)$. Complexes $[3]^{+}$were obtained in up to quantitative yields, feature a wide range of substituents, are stable under ambient conditions, and could be purified using column chromatography. Structural characterization via $\mathrm{X}$-ray diffraction for $\mathrm{R}=p-\mathrm{Br}, p-\mathrm{NO}_{2}, p-\mathrm{NMe}_{2}$, and $p-(\mathrm{C} \equiv \mathrm{CPh})$ proved their constitution. The Fe-nitroso interaction involves a high degree of $\mathrm{Fe} \rightarrow \mathrm{N}(\mathrm{O})$ backbonding, evinced by a range of spectroscopic and structural data. Terminal alkynyl and cyano functionalities are superior binding entities compared to the $\mathrm{NO}_{2} \rightarrow \mathrm{NO}$ reduction process. The reaction is most probably initiated by coordination of two $\{\mathrm{Fe}(\mathrm{dppe}) \mathrm{Cp}\}^{+}$fragments towards the nitro functionality, resulting in the formation of the blue, bimetallic $\left[\{\mathrm{Fe}(\mathrm{dppe}) \mathrm{Cp}\}_{2}\left\{\mu, \kappa^{2} O, O^{\prime}-\mathrm{O}_{2} \mathrm{NAr}\right\}\right]^{2+}$ species in solution. This air and moisture sensitive compound could be spectroscopically identified in the case of reactions of $\mathbf{1}$ and $\mathrm{Na}\left[\mathrm{BAr}_{4}{ }_{4}\right]$ with 2-fluoro-nitrobenzene. The bimetallic species undergoes a $\mathrm{N}-\mathrm{O}$ bond cleavage resulting in nitroso complexes $[3]^{+}$and a $\mathrm{Fe}^{\mathrm{IV}}=\mathrm{O} / \mathrm{Fe}^{\mathrm{III}}-\mathrm{O}^{--}$species. This process is similar to heme-based degradations of $\mathrm{RNO}_{2}$ poisonings, where the respective nitroso complexes terminates the process, due to their superior stability. The herein reported reaction mimics this process using the iron source as both, the nitrosoaryl and oxygen scavenger. The $\mathrm{Fe}^{\mathrm{IV}}=\mathrm{O}$ species undergoes an internal rearrangement via $\mathrm{C}, \mathrm{H}$ activation of a dppe-related phenyl group, resulting in $\left[\mathrm{Fe}^{\mathrm{III}}\left(\kappa^{3} O, P, P^{\prime}-\mathrm{P}\left(2-\mathrm{O}-\mathrm{C}_{6} \mathrm{H}_{4}\right)(\mathrm{Ph})-\mathrm{C}_{2} \mathrm{H}_{4}-\right.\right.$ $\left.\mathrm{PPh}_{2}\right) \mathrm{Cp}^{+}$, proven by single crystal X-ray diffraction. The results could explain difficulties in the conversion of nitroarenes in iron catalysis.

\section{ASSOCIATED CONTENT}

Supporting Information contains experimental prodecures and spectroscopic of the new compounds described herein. This material is available free of charge via the Internet at http://pubs.acs.org.

\section{AUTHOR INFORMATION}

\section{Corresponding Author}

*M.K. : E: marcus.korb@uwa.edu.au

\section{ACKNOWLEDGMENT}

M.K. gratefully acknowledges support from the Forrest Research Foundation for a Forrest Research Fellowship. This work is further supported in part by the University of Western Australia Research Priorities Fund. The authors gratefully acknowledge the facilities, and the scientific and technical assistance of Microscopy Australian at the Centre for Microscopy, Characterisation \& Analysis (CMCA) and The University of Western Australia, a facility funded by the University, State and Commonwealth Governments. S.A.M gratefully acknowledges the Australian Research Council (ARC) for a Future Fellowship (FT200100243). We gratefully acknowledge helpful discussions with Professor A.S. Weller and advice concerning the synthesis of $\mathrm{Na}\left[\mathrm{BAr}{ }_{4}^{\mathrm{Cl}}\right]$.

\section{REFERENCES}

[1] H.-J. Knölker, Recent Advances in Iron Catalysis, MPDI, Basel, 2020.

$\left.{ }^{2}\right]$ W. Adam, O. Krebs, The Nitroso Ene Reaction: A Regioselective and Stereoselective Allylic Nitrogen Functionalization of Mechanistic Delight and Synthetic Potential. Chem. Rev. 2003, 103, 4131-4146.

${ }^{[3]}$ a) N. C. Tomson, L. A. Labios, T. Weyhermüller, J. S. Figueroa, K. Wieghardt, Redox Noninnocence of Nitrosoarene Ligands in Transition Metal Complexes. Inorg. Chem. 2011, 50, 5763-5776; b) H. Koga, T. Hamadab, S. Sakaki, Methylviologen-pendant iron porphyrins as models of a reduction enzyme: six-electron reduction of nitrobenzene to aniline. Dalton Trans. 2003, 1153-1160; c) P. Gans, J. R. Regnard, P. Battioni, D. Mansuy, Mössbauer study of (2nitrosopropane)(N-Methylimidazole) and (2-Nitrosopropane) (isopropylamine) Iron(II) Tetraphenylporphyrings. Chem. Phys. 1980, $45,401-408$.

${ }^{[4]}$ a) N. Godbout, L. K. Sanders, R. Salzmann, R. H. Havlin, M. Wojdelski, E. Oldfield, Solid-State NMR, Mössbauer, Crystallographic, and Density Functional Theory Investigation of $\mathrm{Fe}-\mathrm{O}_{2}$ and $\mathrm{Fe}-\mathrm{O}_{2}$ Analogue Metalloporphyrins and Metalloproteins. J. Am. Chem. Soc. 1999, 121, 3829-3844; b) L.-S. Wang, L. Chen, M. A. Khan, G. B. Richter-Addo, The first structural studies of nitrosoarene binding to iron-(II) and -(III) porphyrins. Chem. Commun. 1996, 323-324.

$\left[{ }^{5}\right]$ a) Lee, L. Chen, A. H. West, G. B. Richter-Addo, Interactions of Organic Nitroso Compounds with Metals. Chem. Rev. 2002, 102, 1019-1065; b) M. Cameron, B. G. Gowenlock and G. Vasapollo, Coordination Chemistry of C-Nitroso-compounds. Chem. Soc. Rev. 1990, 19, 355-379. 
$\left.{ }^{6}\right]$ a) D. Zhao, M. Johansson, J.-E. Bäckvall, In Situ Generation of Nitroso Compounds from Catalytic Hydrogen Peroxide Oxidation of Primary Aromatic Amines and Their One-Pot Use in Hetero-DielsAlder Reactions. Eur. J. Org. Chem. 2007, 4431-4436; b) B. G. Gowenlock, G. B. Richter-Addo, Preparation of C-Nitroso Compounds. Chem. Rev. 2004, 104, 3315-3340.

$\left[{ }^{7}\right]$ M. S. Askari, M. Orio, X. Ottenwaelder, Controlled nitrene transfer from a tyrosinase-like arylnitroso-copper complex. Chem. Commun. 2015, 51, 11206-11209.

$\left[{ }^{8}\right]$ L.-S. Wang, L. Chen, M. A. Khan, G. B. Richter-Addo, The first structural studies of nitrosoarene binding to iron-(II) and -(III) porphyrins. Chem. Commun. 1996, 323-324.

$\left[{ }^{9}\right]$ a) M. Murayama, The combining power of normal human haemoglobin for nitrosobenzene. J. Biol. Chem. 1960, 235, 1024-1028; b) D. Mansuy, Coordination chemistry of cytochromes P450 and ironporphyrins: relevance to pharmacology and toxicology. Biochimie 1978, 60, 969-977.

$\left[{ }^{10}\right]$ D. Mansuy, P. Battioni, J.-C. Chottard, C. Riche, A. Chiaroni, Nitrosoalkane Complexes of Iron-Porphyrins: Analogy between the bonding properties of nitrosoalkanes and dioxygen. J. Am. Chem. Soc. 1983, 105, 455-463.

[11] J. M. O'Connor, K. D. Bunker, Conversion of $\left(\eta^{5}-\right.$ $\left.\mathrm{C}_{5} \mathrm{H}_{5}\right) \mathrm{Co}\left(\mathrm{PPh}_{3}\right)_{2}$ and Nitro Compounds to Mononuclear $\eta^{1}(N)$ Nitrosoalkyl and Dinuclear $\mu-\eta^{1}(N): \eta^{2}(N, O)$-Nitrosoaryl Complexes. Organometallics 2003, 22, 5268-5273.

${ }^{[12]}$ R. S. Berman, J. K. Kochi, Kinetics and Mechanism of Oxygen Atom Transfer from Nitro Compounds Mediated by Nickel(O) Complexes. Inorg. Chem. 1980, 19, 248-254.

[13] a) M. Pizzotti, C. Crotti, F. Demartin, Deoxygenation of 2Nitrophenol. Synthesis and X-Ray Crystal Structure of $\left.\left[\mathrm{Ru}\left(\mathrm{OC}_{6} \mathrm{H}_{4} \mathrm{NO}-o\right)\left(\mathrm{OC}_{6} \mathrm{H}_{4} \mathrm{NO}_{2}-o\right)(\mathrm{CO})\left(\mathrm{PPh}_{3}\right)_{2}\right]\right)$. J. Chem. Soc., Dalton Trans. 1984, 735-737; b) S. J. Skoog, W. L. Gladfelter, Activation of Nitroarenes in the Homogenous Catalytic Carbonylation of Nitroaromatics via an Oxygen-Atom-Transfer Mechanism Induced by Inner-Sphere Electron Transfer. J. Am. Chem. Soc. 1997, 119, 11049-11060; c) S. J. Skoog, J. P. Cambell, W. L. Gladfelter, Homogeneous Catalytic Carbonylation of Nitroaromatics. 9. Kinetics and Mechanism of the First N-O Bond Cleavage and Structure of the $\eta^{2}$-ArNO Intermediate. Organometallics 1994, 13, 4137-4139.

${ }^{[14]}$ N. Mukherjee, R. Gawin, S. J. Czarnocki, R. Gajda, M. Malińska, K. Woźniak, A. Kajetanowicz, K. Grela, Unexpected formation of nitroso-chelated cyclic $\eta^{1}$-acylruthenium(II) complex, an effective catalysts for transfer hydrogenation reaction. J. Organomet. Chem. 2018, 867, 359-366.

${ }^{[15]}$ S.-C. Chan, C.-Y. Wong, Recent developments in rutheniumnitrosoarene chemistry: Unconventional synthetic strategies, new ligand designs, and exploration of ligands redox non-innocence. Coord. Chem. Rev. 2020, 402, 213082.

${ }^{[16]}$ R. Loska, C. M. Rao Volla, P. Vogel, Iron-Catalyzed MizorokiHeck Cross-Coupling Reaction with Styrenes. Adv. Synth. Catal. 2008, 350, 2859-2864.

[17] a) T. Liu, X. Wang, C. Hoffmann, D. L. DuBois, R. M. Bullock, Heterolytic Cleavage of Hydrogen by an Iron Hydrogenase Model: An Fe-H $\cdots$ H-N Dihydrogen Bond Characterized by Neutron Diffraction. Angew. Chem. Int. Ed. 2014, 53, 5300-5304; b) B. M. Cossairt, C. C. Cummins, Properties and Reactivity Patterns of $\mathrm{AsP}_{3}$ : An Experimental and Computational Study of Group 15 Elemental Molecules. J. Am. Chem. Soc. 2009, 131, 15501-15511, c) E. C. Fitzgerald, A. Ladjarafi, N. J. Brown, D. Collison, K. Costuas, R. Edge, J.-F. Halet, F. Justaud, P. J. Low, H. Meghezzi, T. Roisnel, M. W.
Whiteley, C. Lapinte, Spectroscopic Evidence for Redox Isomerism in the 1,4-Diethynylbenzene-Bridged Heterobimetallic Cation $\left[\left\{\mathrm{Fe}(\mathrm{dppe}) \mathrm{Cp}^{*}\right\}\left(\mu-\mathrm{CtCC}_{6} \mathrm{H}_{4} \mathrm{CC}\right)\left\{\mathrm{Mo}(\mathrm{dppe})\left(\eta-\mathrm{C}_{7} \mathrm{H}_{7}\right)\right\}\right] \mathrm{PF}_{6}$. Organometallics 2011, 30, 4180-4195; d) M. Jiménez-Tenorio, M. C. Puerta, P. Valerga, Half-Sandwich Halide, Alkyl, Hydride, and Related Complexes of Iron Containing the Bulky Diphosphine 1,2-Bis(diisopropylphosphino)ethane. Crystal Structure of $\left[\mathrm{FeH}_{2}\left(\mathrm{C}_{5} \mathrm{Me}_{5}\right)(\right.$ dippe $\left.)\right]\left[\mathrm{BPh}_{4}\right]$. Organometallics 1994, 13, 3330-3337. ${ }^{[18]}$ J. C. Stephens, M. A. Khan, .K. M. Nicholas, Cyclopentadienyliron complexes of nitrosobenzene: Preparation, structure and reactivity with olefins. J. Organomet. Chem. 2005, 690, 4727-4733. [19] H. Song, Z. Yang, C.-H. Tung, W. Wang, Iron-Catalyzed Reductive Coupling of Nitroarenes with Olefins: Intermediate of Iron-Nitroso Complex. ACS Catal. 2020, 10, 276-281.

${ }^{[20]}$ J. B. G. Gluyas, N. J. Brown, J. D. Farmer, P. J. Low, Optimised Syntheses of the Half-Sandwich Complexes $\mathrm{FeCl}(\mathrm{dppe}) \mathrm{Cp}$ *, $\mathrm{FeCl}(\mathrm{dppe}) \mathrm{Cp}, \mathrm{RuCl}(\mathrm{dppe}) \mathrm{Cp}$ *, and $\mathrm{RuCl}(\mathrm{dppe}) \mathrm{Cp}$. Aust. J. Chem. 2017, 70, 113-119.

${ }^{[21]}$ a) Y. Mutoh, Y. Ikeda, Y. Kimura, Y. Ishii, Internal Alkyne-tovinylidene Isomerization at Cationic Ruthenium and Iron Complexes. Chem. Lett. 2009, 38, 534-535; b) M. Otsuka, N. Tsuchida, Y. Ikeda, N. Lambert, R. Nakamura, Y. Mutoh, Y. Ishii, K. Takano, Theoretical Study on Internal Alkyne/Vinylidene Isomerization in Group 8 Transition-Metal Complexes. Organometallics 2015, 34, 3934-3943.

${ }^{[22]}$ a) J. Liu, H. Song, T. Wang, J. Jia, Q.-X. Tong, C.-H. Tung, W. Wang, Iron-Catalyzed Regiodivergent Hydrostannation of Alkynes: Intermediacy of $\mathrm{Fe}(\mathrm{IV})-\mathrm{H}$ versus $\mathrm{Fe}(\mathrm{II})-$ Vinylidene. J. Am. Chem. Soc. 2021, 143, 409-419; b) M. D. Walter, P. S. White, Reactivity Studies on $\left[\mathrm{Cp}^{\prime} \mathrm{Fe}\right]$ 2: Monomeric Amido, Phenoxo, and Alkyl Complexes. Inorg. Chem. 2012, 51, 11860-11872; c) M. Wallasch, G Wolmershäuser, H. Sitzmann, Phenolate Complexes of Iron(II) in Different Spin States. Angew. Chem. Int . Ed. 2005, 44, 2597 -2599; Angew. Chem. 2005, 117, 2653-2655.

${ }^{[23]}$ For computational investigations see: a) Q. Zeng, Z. Li, D. Han, L. Dong, H. Zhai, B. Liu, G. Bai, Y. Zhang, Hartree-Fock and density functional theory study of remote substituent effects on gasphase heterolytic $\mathrm{Fe}-\mathrm{O}$ and $\mathrm{Fe}-\mathrm{S}$ bond energies of $p-\mathrm{G}_{-} \mathrm{C}_{6} \mathrm{H}_{4} \mathrm{OFe}(\mathrm{CO})_{2}\left(\eta^{5}-\right.$ $\left.\mathrm{C}_{5} \mathrm{H}_{5}\right)$ and $p-\mathrm{G}_{-} \mathrm{C}_{6} \mathrm{H}_{4} \mathrm{SFe}(\mathrm{CO})_{2}\left(\eta^{5}-\mathrm{C}_{5} \mathrm{H}_{5}\right)$. J. Phys. Org. Chem. 2014, 27, 142-155; b) Q. Zeng, Z. Li, Y.-B. Wang, H. Zhaia, O. Tao, Y. Wang, J. Guan, Y. Zhang, Substituent effects on gas-phase hemolytic $\mathrm{Fe}-\mathrm{O}$ and $\mathrm{Fe}-\mathrm{S}$ bond energies of $m-\mathrm{G}-\mathrm{C}_{6} \mathrm{H}_{4} \mathrm{OFe}(\mathrm{CO})_{2}\left(\eta^{5}-\mathrm{C}_{5} \mathrm{H}_{5}\right)$ and $m$-G- $\mathrm{C}_{6} \mathrm{H}_{4} \mathrm{SFe}(\mathrm{CO})_{2}\left(\eta^{5}-\mathrm{C}_{5} \mathrm{H}_{5}\right)$ studied using Hartree-Fock and density functional theory methods. J. Phys. Org. Chem. 2016, 29, 172-184; c) Q. Zeng, Z. Li, L. Dong, D. Han, R. Wang, X. Li, G. Bai, Remote substituent effects on gas-phase homolytic $\mathrm{Fe}-\mathrm{O}$ and $\mathrm{Fe}-\mathrm{S}$ bond energies of $p-\mathrm{G}-\mathrm{C}_{6} \mathrm{H}_{4} \mathrm{OFe}(\mathrm{CO}) 2\left(\eta^{5}-\mathrm{C}_{5} \mathrm{H}_{5}\right)$ and $p$-G$\mathrm{C}_{6} \mathrm{H}_{4} \mathrm{SFe}(\mathrm{CO})_{2}\left(\eta^{5}-\mathrm{C}_{5} \mathrm{H}_{5}\right)$ studied using Hartree-Fock and density functional theory methods. J. Phys. Org. Chem. 2013, 26, 664-674.

${ }^{[24]}$ For reactions of half-sandwich complexes with phenols, not resulting in phenolates, see: a) S. Yasuda, H. Yorimitsu, K. Oshima, Synthesis of Functionalized Aryliron Complexes $\left[\mathrm{CpFe}(\mathrm{CO})_{2} \mathrm{Ar}\right]$ by Copper-Mediated Transmetalation between $\left[\mathrm{CpFe}(\mathrm{CO})_{2} \mathrm{I}\right]$ and Aryltin Reagents. Organometallics 2010, 29, 273-274; b) C. Díaz, E. Spodine, Y. Moreno, E. Carrasco, A one step functionalization, coordination of $\mathrm{N}_{3} \mathrm{P}_{3} \mathrm{Cl}_{6}$ using $\left[\mathrm{CpFe}(\text { dppe }) \mathrm{SC}_{6} \mathrm{H}_{4} \mathrm{OH}\right]^{+}$. J. Chil. Chem. Soc. 2004, 49, 205-207; c) J. Peng, Y.-S. Wen, L.-K. Liu, Reaction of $\left(\eta^{5}-\mathrm{C}_{5} \mathrm{H}_{5}\right) \mathrm{Fe}(\mathrm{CO})_{2} \mathrm{I}$ with Anionic Bidentate Phosphine Ligands $\mathrm{PPh}_{2}\left(o-\mathrm{C}_{6} \mathrm{H}_{4} \mathrm{NHLi}\right)$ or $\mathrm{PPh} 2(\mathrm{o}-\mathrm{C} 6 \mathrm{H} 4 \mathrm{Oli})$. J. Chin. Chem. Soc. 2001, 48, 833-841; d) Y. Matsuura, Y. Tanaka, M. Akita, $p$ Diethynylbenzene-based molecular wires, $\mathrm{Fe}-\mathrm{C} \equiv \mathrm{C}-p-\mathrm{C}_{6} \mathrm{H}_{2} \mathrm{X}_{2}-\mathrm{C} \equiv \mathrm{C}-\mathrm{Fe}$ 
$\left[\mathrm{Fe}=\mathrm{Fe}\left(\eta^{5}-\mathrm{C}_{5} \mathrm{Me}_{5}\right)(\mathrm{dppe})\right]:$ Synthesis, substituent effects and unexpected formation of benzodifuran complex. J. Organomet. Chem. 2009, 694, 1840-1847.

${ }^{[25]}$ The nitroso stretching could only be observed for $\left[\mathrm{BAr}^{\mathrm{Cl}}\right]^{-}$. Instead, $\left[\mathrm{Bar}_{4}\right]^{-}$supersedes the stretching, even if the spectra of [4] $\left[\mathrm{BAr}^{\mathrm{F}}{ }_{4}\right]$ was subtracted. Spectra are provided in the ESI.

${ }^{[26]}$ C. Hansch, A. Leo, R. W. Taft, A survey of Hammett Substituted Constants and Resonance and Field Parameters. Chem. Rev. 1991, 91, 165-195.

${ }^{27}$ For NMR investigations of $[4]^{+}$-type complexes, see: C. Roger, P. Hamon, L. Toupet, H. Rabaa, J.-Y. Saillard, J.-R. Hamon, C. Lapinte, Alkyl(pentamethylcyclopentadienyl) (1,2-bis(diphenylphosphino)ethane)iron(III) 17-Electron Complexes: Synthesis, NMR and Magnetic Properties, and EHMO Calculations. Organometallics 1991, 10, 1045-1054.

${ }^{[28]}$ D. Patel, A. Wooles, A. D. Cornish, L. Steven, E. S. Davies, D. J. Evans, J. McMaster, W. Lewis, A. J. Blake, S. T. Liddle, Synthesis and characterisation of halide, separated ion pair, and hydride cyclopentadienyl iron bis(diphenylphosphino)ethane derivatives. Dalton Trans. 2015, 44, 14159-14177.

$\left[{ }^{29}\right]$ P. Gütlich, E. Bill, A. X. Trautwein, Mössbauer Spectroscopy and Transition Metal Chemistry, Fundamentals and Application, Springer, Berlin, Heidelberg, 2011, pp 86-102.

$\left[{ }^{30}\right]$ M. Tilset, I. Fjeldahl, J.-R. Hamon, P. Hamon, L. Toupet, J.-Y. Saillard, K. Costuas, A. Haynes, Theoretical, Thermodynamic, Spectroscopic, and Structural Studies of the Consequences of OneElectron Oxidation on the $\mathrm{Fe}-\mathrm{X}$ Bonds in 17- and 18-Electron $\mathrm{Cp} * \mathrm{Fe}(\mathrm{dppe}) \mathrm{X}$ Complexes $\left(\mathrm{X}=\mathrm{F}, \mathrm{Cl}, \mathrm{Br}, \mathrm{I}, \mathrm{H}, \mathrm{CH}_{3}\right)$. J. Am. Chem. Soc. 2001, 123, 9984-10000.

${ }^{[31]}$ P. Hamon, L. Toupet, T. Roisnel, J. R. Hamon, C. Lapinte, Preparation and Characterization of the Triflate Complex [Cp*(dppe) $\mathrm{FeOSO}_{2} \mathrm{CF}_{3}$ ]: A Convenient Access to Labile Five- and Six-Coordinate Iron(I) and Iron(II) Complexes. Eur. J. Inorg. Chem. 2020, 84-93.

$\left[{ }^{32}\right]$ a) A. B. Chaplin, A. S. Weller, $\left[\mathrm{B}\left(3,5-\mathrm{C}_{6} \mathrm{H}_{3} \mathrm{Cl}_{2}\right)_{4}\right]^{-}$as a Useful Anion for Organometallic Chemistry. Eur. J. Inorg. Chem. 2010, 5124-5128; b) R. Anulewicz-Ostrowska, T. Kliś, D. Krajewski, B. Lewandowski, J. Serwatowski, Synthesis of some halogenated tetraarylborates. Tetrahedron Lett. 2003, 44, 7329-7311.

${ }^{[33]}$ The red $\left[\mathrm{Fe}\left(\right.\right.$ nitromethane)(dppe) $\mathrm{Cp}_{\mathrm{P}} \mathrm{PF}_{6}$ complex did not show a blue color upon its formation from [FeI(dppe)Cp] with $\mathrm{TlPF}_{6}$ in a). a) C. Díaz, N. Yutronic, Coordinating Properties of Some Solvents Towards the Fragment CpFe(dppe) ${ }^{+}$. Polyhedron 1996, 15, 9971001; b) T. E. Bauch, H. Konowitz, W. P. Giering, Cationic Iron Complexes Containing the $\eta^{2}$-Butatriene Ligand. J. Organomet. Chem. 1976, 114, C15-C18; c) E. K. G. Schmidt, C. H. Thiel, Eine effiziente Methode zur Darstellung neuer Komplexes des Kations $\left[\left(\text { Dicarbonyl)(Ligand)( } \eta^{5} \text {-Cyclopentadienyl)Eisen }\right]^{+}\right.$. J. Organomet. Chem. 1981, 209, 373-384; d) A. Cutler, D. Ehntholt, W. P. Giering, P. Lennon, S. Raghu, A. Rosan, M. Rosenblum, J. Tancrede, D. Wells, Chemistry of Dicarbonyl $\eta^{5}$-Cyclopentadienyl- $\eta^{1}$-allyl- and $\eta^{2}$-olefiniron Complexes. Preparation and Cycloaddition Reactions. J. Am. Chem. Soc. 1976, 98, 3495-3507.

${ }^{[34]}$ R. S. Srivastava, M. A. Khan, K. M. Nicholas, Preparation and molecular structure of $\left[\left(\eta^{5}-\mathrm{C}_{5} \mathrm{H}_{5}\right) \mathrm{Fe}(\mathrm{CO})_{2}\left(\eta^{1}-\mathrm{PhNO}_{2}\right)\right] \mathrm{BF}_{4}$. Inorg. Chim. Acta 2003, 349, 269-272.

${ }^{[35]}$ The absence of nitro functionalities in common aromatics, such as toluene, benzene, benzonitrile and diphenylacetylene, does not result in a blue coloured solution, excluding a $\pi$-coordination of arenes. $\left.{ }^{[36}\right]$ a) N. Fukui, X.-X. Li, W. Nam, S. Fukuzumi, H. Fujii, Small Reorganization Energy for Ligand-Centered Electron-Transfer Reduction of Compound I to Compound II in a Heme Model Study. Inorg. Chem. 2019, 58, 8263-8266; b) J. Hohenberger, K. Ray, K. Meyer, The biology and chemistry of high-valent iron-oxo and ironnitrido complexes. Nature Commun. 2012, 3, 720; c) H. Fujii, Electronic structure and reactivity of high-valent oxo iron porphyrins. Coord. Chem. Rev. 2002, 226, 51-60; d) W. Nam, Y. O. Ryu, W. J. Song, Oxidizing intermediates in cytochrome $\mathrm{P} 450$ model reactions. J. Biol. Inorg. Chem. 2004, 9, 654-660.

${ }^{[37]}$ D. B. Pardue, J. Mei, T. R. Cundari, T. B. Gunnoe, Density Functional Theory Study of Oxygen-Atom Insertion into Metal-Methyl Bonds of Iron(II), Ruthenium(II), and Osmium(II) Complexes: Study of Metal-Mediated $\mathrm{C}-\mathrm{O}$ Bond Formation. Inorg. Chem. 2014, 53, 2968-2975. 
Insert Table of Contents artwork here - For Table of Contents Only
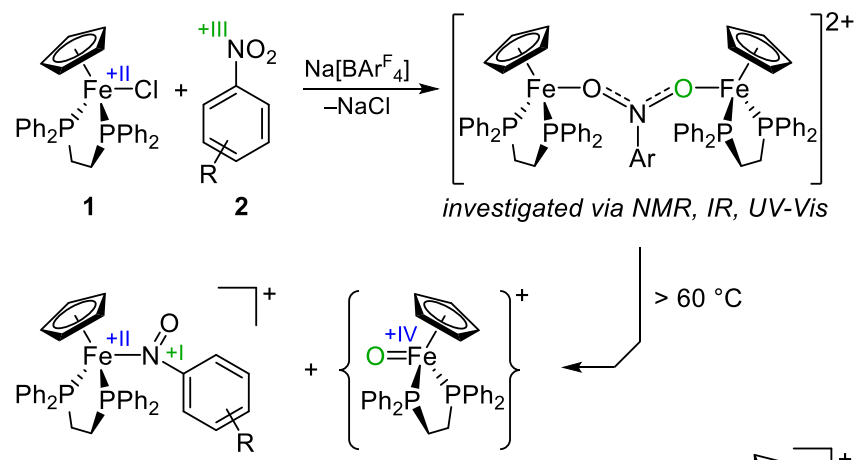

$$
\text { [3][BArF } \left.{ }_{4}\right]
$$

- 18 examples

- up to $50 \%$ yield

- X-ray diffraction

. ${ }^{57} \mathrm{Fe}$ Mössbauer
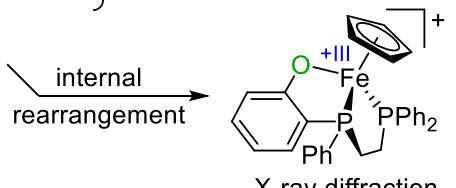

\section{Synopsis}

Reaction of $[\mathrm{Fe}(\text { dppe }) \mathrm{Cp}]^{+}$with nitro aromatics $\mathrm{RC}_{6} \mathrm{H}_{4} \mathrm{NO}_{2}\left(\mathrm{R}=\right.$ halogen, $\mathrm{Me}, \mathrm{OMe}, \mathrm{NO}_{2}$ or $\left.\mathrm{NMe}_{2}\right)$ gave cationic iron nitroso complexes $\left[\mathrm{Fe}\left\{\mathrm{N}(\mathrm{O})-\mathrm{C}_{6} \mathrm{H}_{4} \mathrm{R}\right\}(\mathrm{dppe}) \mathrm{Cp}\right]^{+}\left([3]^{+}\right)$. Their formation likely proceeds via the unusual, blue-coloured bimetallic species $\left[\{\mathrm{Fe}(\mathrm{dppe}) \mathrm{Cp}\}_{2}\left\{\mu, \kappa^{2} O, O^{\prime}-\mathrm{O}_{2} \mathrm{NAr}\right\}\right]^{2+}$. This compound undergoes $\mathrm{N}-\mathrm{O}$ bond cleavage resulting in $[3]^{+}$and an $\mathrm{Fe}^{\mathrm{IV}}=\mathrm{O}$ species, which reacts via an internal $\mathrm{C}-\mathrm{H}$ activation of the dppe ligand to give $\left[\mathrm{Fe}^{\mathrm{III}}\left(\kappa^{3} O, P, P^{\prime}-\mathrm{P}\left(2-\mathrm{O}-\mathrm{C}_{6} \mathrm{H}_{4}\right)(\mathrm{Ph})-\mathrm{C}_{2} \mathrm{H}_{4}-\mathrm{PPh}_{2}\right) \mathrm{Cp}^{+}\right.$. 